Provided for non-commercial research and education use. Not for reproduction, distribution or commercial use.

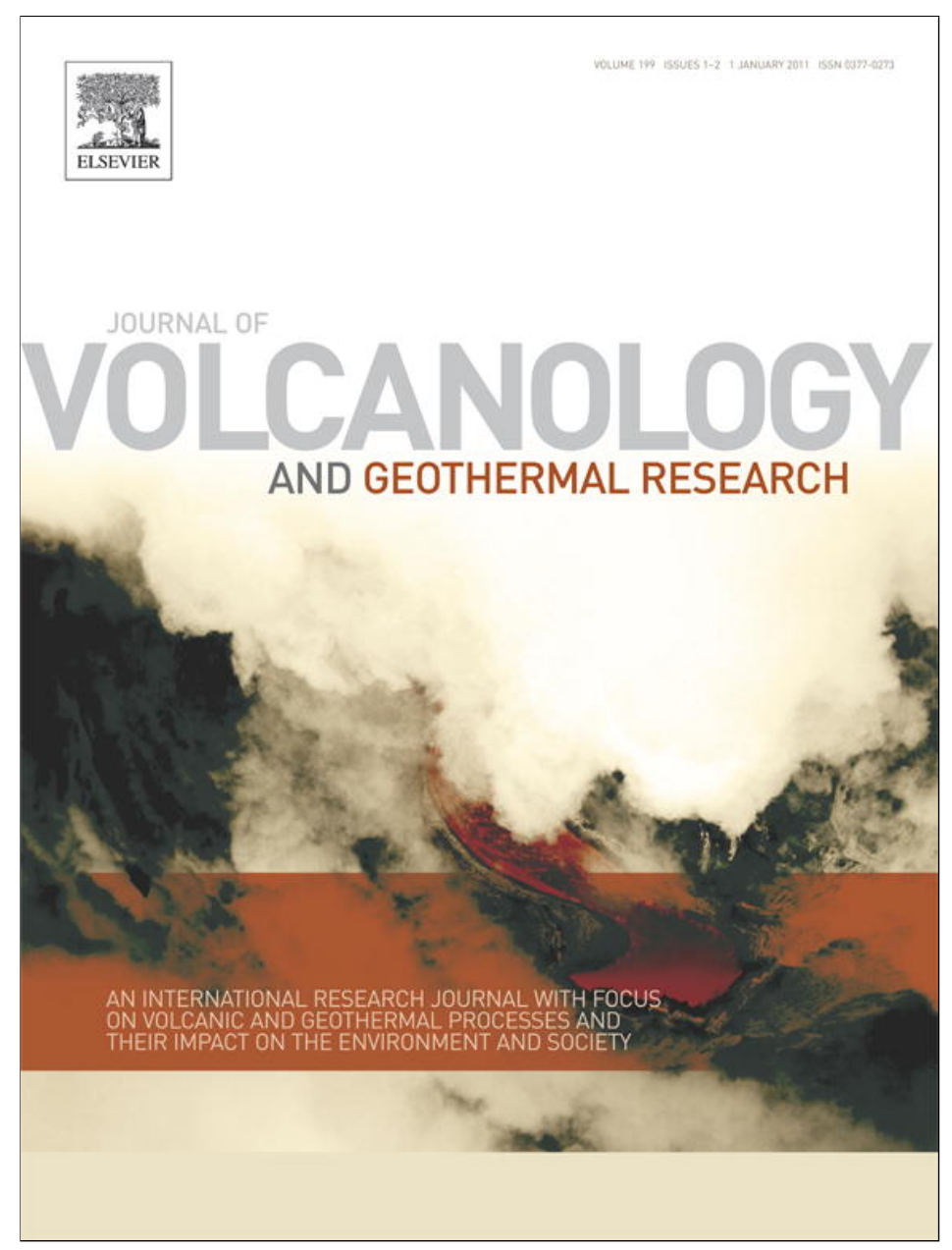

(This is a sample cover image for this issue. The actual cover is not yet available at this time.)

This article appeared in a journal published by Elsevier. The attached copy is furnished to the author for internal non-commercial research and education use, including for instruction at the authors institution and sharing with colleagues.

Other uses, including reproduction and distribution, or selling or licensing copies, or posting to personal, institutional or third party websites are prohibited.

In most cases authors are permitted to post their version of the article (e.g. in Word or Tex form) to their personal website or institutional repository. Authors requiring further information regarding Elsevier's archiving and manuscript policies are encouraged to visit:

http://www.elsevier.com/copyright 


\title{
Radiative heat power at Stromboli volcano during 2000-2011: Twelve years of MODIS observations
}

\author{
D. Coppola ${ }^{\mathrm{a}, *}$, D. Piscopo ${ }^{\mathrm{a}}$, M. Laiolo ${ }^{\mathrm{a}}, \mathrm{C}_{\text {. Cigolini }}{ }^{\mathrm{a}}$, D. Delle Donne ${ }^{\mathrm{b}}$, M. Ripepe ${ }^{\mathrm{b}}$ \\ a Dipartimento di Scienze Mineralogiche e Petrologiche, Università di Torino, Italy \\ b Dipartimento di Scienze della Terra, Università di Firenze, Italy
}

\section{A R T I C L E I N F}

\section{Article history:}

Received 13 July 2011

Accepted 2 December 2011

Available online 13 December 2011

\section{Keywords:}

MODIS

Stromboli

Radiative power

Magma level

Effusive activity

\begin{abstract}
A B S T R A C T
Twelve years of night-time MODIS (Moderate Resolution Imaging Spectroradiometer) observations, has been analysed to detect and quantify the radiative heat power emitted by Stromboli volcano (from March 2000 to September 2011). Using an accurate background subtraction of the MODIS signal at $4 \mu \mathrm{m}$, we were able to discriminate two main regimes of thermal radiation, related to different levels of volcanic activity. Effusive eruptions (occurred on December 28, 2002 and February 27, 2007) radiated at an average of $\sim 186 \mathrm{MW}$ with a frequency of alert detection of 50-95\%. Conversely, during the typical strombolian activity, an average of $\sim 9 \mathrm{MW}$ is radiated, with a frequency of alert detection of $0-45 \%$.

Although during the effusive eruptions the radiative power is basically controlled by the lava discharge rate, our results suggest that during non-effusive periods (strombolian regime) both the intensity and the frequency of MODIS alerts are controlled by the height of the magmatic column feeding the activity at the surface. In particular we found that a radiative power of $\sim 50 \mathrm{MW}$ corresponds to a high magma column which is exposed, in the vent area, at the same rate in which the deeper gas-rich magma is typically supplied within the feeding system of Stromboli $\left(\sim 0.3 \mathrm{~m}^{3} \mathrm{~s}^{-1}\right)$. In this condition the magmatic system approaches steady state regimes. Above this threshold a transition from strombolian to effusive regimes may occur as shown by the detection of $\sim 50 \mathrm{MW}, 8-10$ days before the onset of both the last two major flank eruptions. These values were reached after 1-2 months of gradual increase of the radiative power which was likely associated the rising of the magma column within the shallowest portion of the conduit. In addition our data suggest that over the years 2000-2011 several cycles of rise and fall of the magma column have occurred, which however did not culminate into an effusive eruption but only into recurrent episodes of sustained spattering or fountaining and summit overflows. These fluctuations has substantially increased in frequency and intensity after the 2007 eruption thus suggesting that this event has perturbed in some way the shallow plumbing system of Stromboli.

We stress that the detection of a radiative power higher than $50 \mathrm{MW}$ is a clear evidence of a very high magma column, which may prelude the onset of an effusive eruption and/or periods of sustained vent activity. In conclusion, we suggest that systematic analysis of MODIS data can be used to detect variations in the intensity of strombolian activity and may considerably improve volcano surveillance at Stromboli, as well as at other open-system volcanoes.
\end{abstract}

(C) 2011 Elsevier B.V. All rights reserved.

\section{Introduction}

The use of satellites for detecting and quantifying thermal anomalies due to volcanic activity has been systematically applied in recent years. Most notably, the MODIS instrument (Moderate Resolution Imaging Spectroradiometer), aboard the Terra (EOS AM) and Aqua (EOS PM) satellites, offers a temporal coverage $\left(\sim 4\right.$ images day $\left.{ }^{-1}\right)$, spatial resolution ( $1 \mathrm{~km}$ in the IR bands) and an adequate spectral coverage (the "fire

* Corresponding author at: Dipartimento di Scienze Mineralogiche e Petrologiche, Università di Torino, Via Valperga Caluso 35, 10129 Turin, Italy. Tel.: + 39116705107 E-mail address: diego.coppola@unito.it (D. Coppola). channel" at $\sim 4 \mu \mathrm{m}$ on MODIS band 21) which enables the detection, quantification, and monitoring of volcanic activity in different geotectonic contexts (Wright et al., 2004; Rothery et al., 2005). Stromboli is an open-system volcano characterised by persistent activity routinely monitored with several surveillance networks (Barberi et al., 2009). Therefore, it is a natural laboratory to test adequate methodologies for analysing MODIS data in relation to changes in volcanic activity.

A variety of algorithms have been developed for detecting thermal anomalies from MODIS data automatically. These include the widely used MODIS Fire Algorithm (Giglio et al., 2003), developed for forest fire detection, as well as the MODVOLC algorithm (Flynn et al., 2002; Wright et al., 2002a) which is routinely used for monitoring volcanic activity on a global scale. This last is based on the different 
sensibilities of the radiance recorded on MODIS bands $21(\sim 4 \mu \mathrm{m})$ and $32(\sim 12 \mu \mathrm{m})$ in the presence of a subpixel hotspot. Accordingly, a Normalised Thermal Index (NTI), calculated as the ratio between the difference and the sum of the mentioned radiances ( $\left[\mathrm{L}_{4 \mu \mathrm{m}}\right.$ $\left.-\mathrm{L}_{12 \mu \mathrm{m}}\right] /\left[\mathrm{L}_{4 \mu \mathrm{m}}+\mathrm{L}_{12 \mu \mathrm{m}}\right]$ ), is used to enhance the presence of a thermal anomaly and to automatically detect a hotspot when the NTI of a pixel exceeds a fixed threshold (NTI $=-0.8$ for night time MODIS data; see Wright et al., 2002a for details). However the nature of the algorithm, which has been developed for global-scale monitoring, is such that high thresholds were used to reduce the incidence of false positives: this has the effect of making the algorithm less sensitive to smaller (and/or cooler) volcanic heat sources. More recently other algorithms have been proposed to increase the capability of MODIS to detect small thermal anomalies. For example Vaughan et al. (2008) developed a new algorithm (MODLEN) that gives the opportunity to detect low temperature carbonate-rich lavas at Ol Doinyo Lengai, whereas Marchese et al. (2010) suggest the use of an extensive, multi-temporal analysis of long-term time series (the RST approach; Pergola et al., 2004) to better analyse volcanic activity. Hybrid approach (which use MODVOLC and RST algorithms together) has been also tested, and shown a rather improved performance in detecting low temperature thermal anomalies (Koeppen et al., 2011). However Steffke and Harris (2011) suggests that none of the algorithms performs perfectly but rather each one operates well within the limits and criteria of its design requirements.

In this paper, we analysed MODIS data for Stromboli with the aim of detecting and quantifying the thermal output from the volcano during about 12 years of activity (2000-2011). The method we propose is based on a comparison of the MODIS signal recorded over Stromboli with that recorded over a non-volcanic area (i.e. Salina island) with similar topography and climatic condition (Piscopo, 2010). This approach is similar to that used by Wright et al., 2002b in which the thermal behaviour of Popocatépetl volcano (Mexico) was compared with that of its inactive neighbour (Iztaccihuatl) as a control. This allows to reduce the effect of seasonal background and gave as the possibility to detect the smallest thermal anomalies associated with volcanic activity of Stromboli.

In addition to the two effusive eruptions of Stromboli, occurred on December 28, 2002 and February 27, 2007, respectively (Ripepe et al., 2005; Neri and Lanzafame, 2008; Marsella et al., 2009; Calvari et al., 2010,2011 ) our analysis is particularly focussed on quantifying the long term volcanic radiative power (hereby defined as VRP) produced by "typical" strombolian activity. Therefore we explain the methodology used and discuss the results in the light of the recent volcanic activity.

\section{Stromboli volcano}

Stromboli volcano is a key-case of persistent mild explosive activity, related to an open-conduit dynamics, started 2 ky ago (Rosi et al., 2000). The volcano was built on a 15 to $20 \mathrm{~km}$ thick continental crust and rises from the Tyrrhenian abyssal plane for about $3 \mathrm{~km}$. The emerged part of the cone reaches an elevation of $924 \mathrm{~m}$ a.s.l. and the current activity is concentrated within a crater area, a NE-SW elongated depression, located in the upper part of Sciara del Fuoco (Fig. 1).

The plumbing system is characterised by a deep magmatic reservoir located at 5-10 km depth, where a low porphyritic magma is generated (cf. Francalanci et al., 2005; Cigolini et al., 2008; Metrich et al., 2009). This deep reservoir is connected to the vents trough an intermediate storage zone placed at the base of the volcanic apparatus (at $3 \mathrm{~km}$ depth). From this level, an efficient convective regime allows degassing and crystallisation processes, with the production of the high porphyritic magma which fed the typical strombolian activity (cf. Francalanci et al., 2005; Landi et al., 2006; Aiuppa et al., 2010; Metrich et al., 2009). The shallow plumbing system behaves as an elongated degassing cell (with size $\sim 12 \pm 3 \mathrm{Mm}^{3}$; Allard et al., 2008) where the separation between magma and gas causes a significant unbalance between the degassed and the erupted magma measured at the vents. The persistent $\mathrm{SO}_{2}$ gas flux of $\sim 200 \mathrm{t} \mathrm{day}^{-1}$ (Burton et al., 2007), indicates that the magma is supplied at a rate of $\sim 0.3 \mathrm{~m}^{3} \mathrm{~s}^{-1}$ (Harris and Stevenson, 1997a; Harris and Ripepe, 2007b; Allard et al., 2008) which is approximatively one order of magnitude higher than the long term magma extrusion rate $\left(\sim 0.018 \mathrm{~m}^{3} \mathrm{~s}^{-1}\right.$; Allard et al., 2008). As a consequence, the most of the un-erupted magma ( $93 \%)$ is cycled back and stored beneath the volcano (Allard et al., 2008).

The typical strombolian activity takes place from several vents (from 3 to 9 according to Harris and Ripepe, 2007a) located within the crater area (see Fig. 1). This activity is characterised by the ejection of bombs, black scoria, lapilli and ash, every 10-20 min, accompanied by continuous degassing (Barberi et al., 1993). However, temporal fluctuations of the gas flux promote changes of the magma level within the conduit, as well as variations in the frequency of strombolian explosions and vent temperatures (Harris and Ripepe, 2007a; Ripepe et al., 2008). A drastic departure from this persistent activity is observed during, discrete major explosions, during violent paroxysms and during episodic effusive eruptions (Barberi et al., 1993). Between 2000 and 2011, two effusive eruptions occurred on Stromboli on December 28, 2002 and February 27, 2007, respectively. Both the eruptions originated from the injection of a NE-SW aligned dike departing from the central conduit which fed the respective lava fields (Fig. 5) at a mean output rate of $\sim 0.7 \mathrm{~m}^{3} \mathrm{~s}^{-1}$

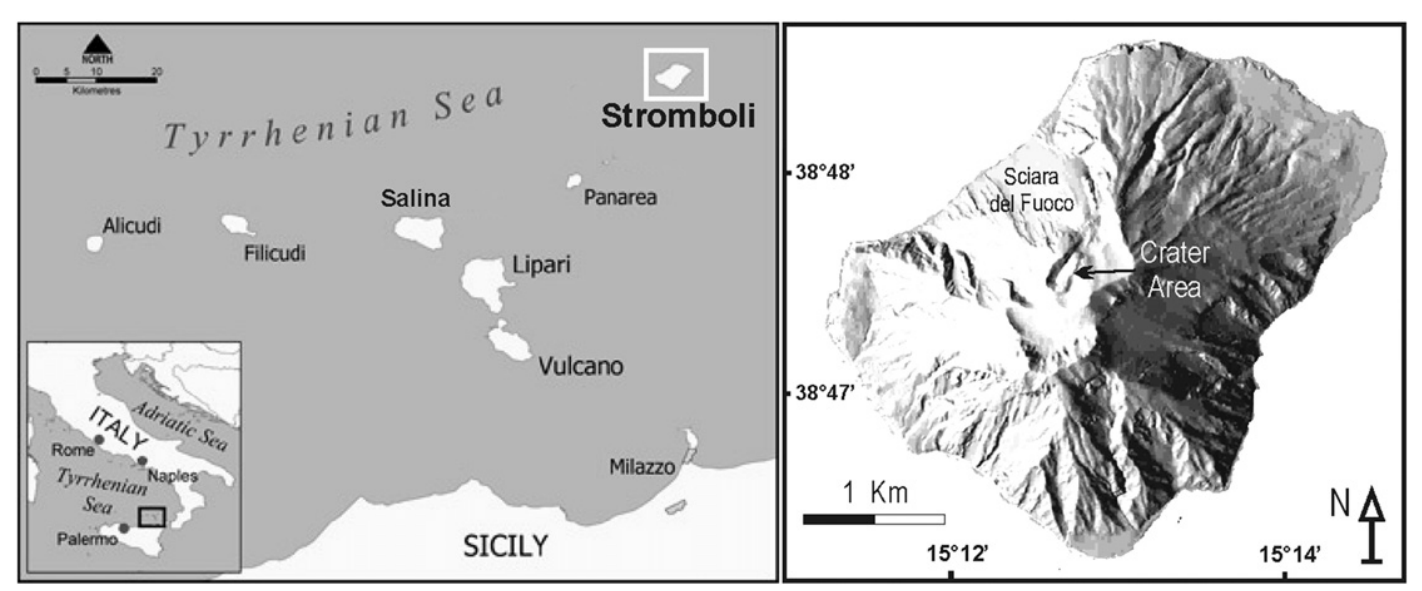

Fig. 1. Location and shaded relief map of Stromboli volcano. The typical strombolian activity takes place within the crater area, a depressed structure located in the upper part of the Sciara del Fuoco. 
and $\sim 3.8 \mathrm{~m}^{3} \mathrm{~s}^{-1}$ (for the December 2002 and February 2007 eruptions, respectively; cf.; Calvari et al., 2005, 2010, 2011; Lodato et al., 2007; Marsella et al., 2009, in press). On the whole approximatively 13 and $11 \mathrm{Mm}^{3}$ of lava, were emplaced by these eruptions which represent two of the most voluminous lava flows produced by Stromboli in the last century (Marsella et al., in press).

\section{Data analysis}

We used night-time MODIS level 1b data (freely available on http://ladsweb.nascom.nasa.gov/) acquired by NASA's Terra (launched on December 1999) and Aqua (launched on May 2002) satellites which allow Stromboli volcano to be imaged approximatively two times per day (since May 2002). The whole data set, consisting on more than 8600 images, has been analysed by processing each MODIS overpass according to six principal steps which are described in the next paragraphs. These are: (i) removal of bow-tie effect, (ii) resampling into UTM projection, (iii) detection of the thermal-anomalous pixel/s, (iv) calculation of the apparent anomaly at $4 \mu \mathrm{m}\left(\Delta \mathrm{L}_{4 \mathrm{STR}}\right)$ (v) subtraction of the residual background and estimation of $\mathrm{L}_{4 \mathrm{VOLC}}$, (vi) estimation of the volcanic radiative power (VRP).

\subsection{Step i: Removal of bow-tie effect}

The MODIS detector array has ten detectors in a column which acquires images over a scan range of $-55^{\circ}$ to $+55^{\circ}$. Each detector samples an area on the ground of $1 \mathrm{~km}^{2}$ at nadir, and each mirror scan therefore simultaneously samples radiance from $10 \mathrm{~km}$ in the in track direction. At the edge of the swath the projected area effect means that the same 10 detectors then sample an area $20 \mathrm{~km}$ long, in the in-track direction. As a result, at nadir, adjacent mirror scans a sample of 10 ground resolution elements which abut each other; at the edge of the swath, adjacent scans overlap.

For scan angles greater than $25^{\circ}$, this may produce a scan-to-scan overlap (bow tie effect) with the consequence that the area viewed by a detector may be also viewed by adjacent detectors (Nishihama et al., 1997). In terms of volcano surveillance the bow tie effect may thus produce a double counting (sometimes a triple counting for extreme viewing geometry), that may cause an overestimate of the total thermal anomaly. To remove the bow-tie effect we apply the procedure described by Liu et al. (2008) that filters the pixels looking at surface areas already sampled by adjacent pixel/s.

\subsection{Step ii: Resampling and normalised thermal index (NTI)}

In addition to the bow-tie effect, high scan angle contributes to the growth of the projected ground spatial element so that for a scan angle of $55^{\circ}$ the pixel samples approximatively $10 \mathrm{~km}^{2}$ $(2 \times 4.8 \mathrm{~km})$ of surface (Nishihama et al., 1997). This leds the radiance of a potential subpixel hotspot to be integrated over a variable area, according to the viewing geometry. To avoid this problem the original MODIS level1b data, falling within a mask $(50 \times 50 \mathrm{~km})$ centred over the summit of Stromboli, has been cropped and resampled into UTM grid of $1 \mathrm{~km}$ in cell size. This means that hot-spot pixel whose area was $2 \mathrm{~km}^{2}$, in the original image, became two equal area $1 \mathrm{~km}^{2}$ pixels in the resampled image. The resampled radiance at 4 and $12 \mu \mathrm{m}$ (original MODIS band 21/22 and 32) is then used to calculate the NTI of each pixel and to produce an NTI map as illustrated in Fig. 2 . In the next steps any processing is applied to these resampled pixels.

(a)

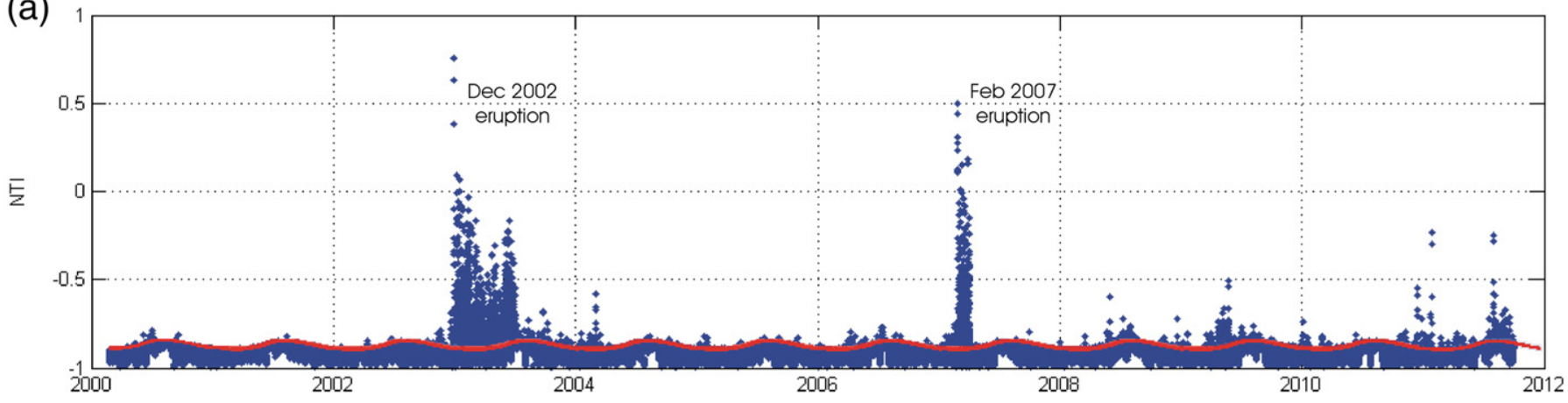

(b)

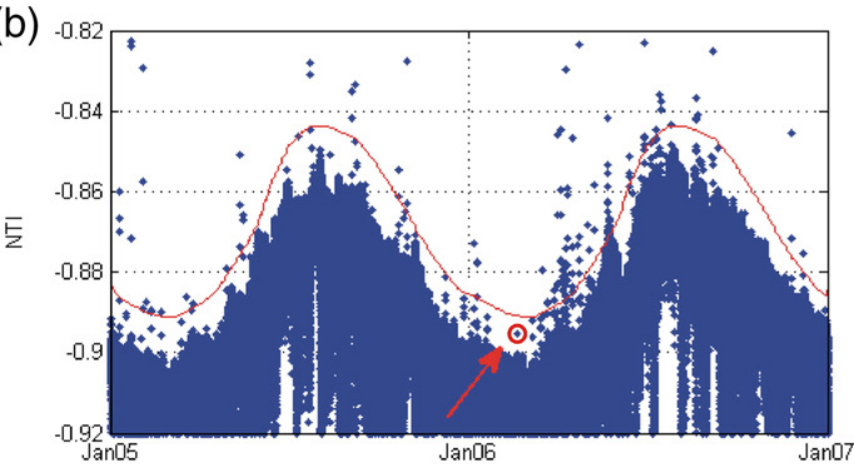

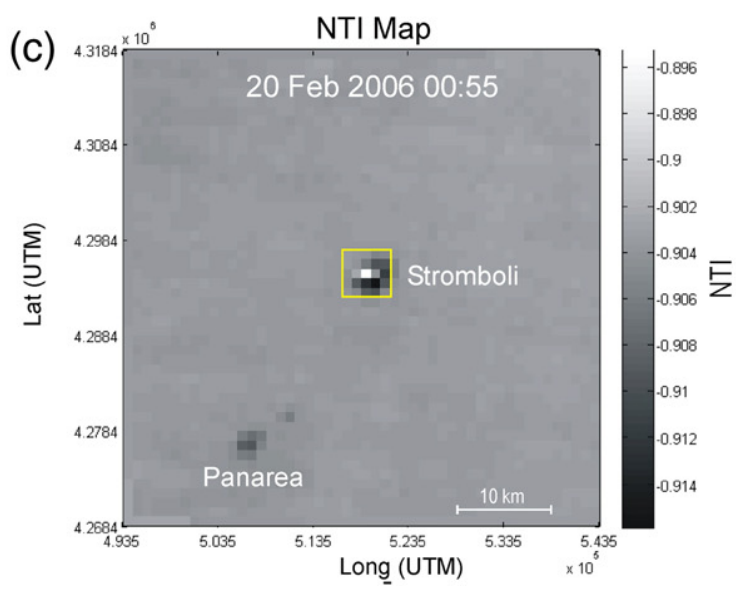

Fig. 2. (a) Time series of the NTI during 2000-2011 period. Red line represents the NTI threshold adapted for the seasonal background. The two periods of very high NTI correspond to the December 2002 and February 2007 eruptions. (b) Zoom of the NTI time series between 2005 and 2007. Note how the pixel below the threshold (i.e. 20 February 2006 00:55; red arrow) is clearly associated to a small thermal anomaly on the summit of Stromboli (c), visible on the NTI map. (For interpretation of the references to colour in this figure legend, the reader is referred to the web version of this article.) 


\subsection{Step iii: Detection of the thermal-anomalous pixel/s}

For each acquisition date, we looked at the detection of the pixel (s) "surely" or "potentially" contaminated by a thermal anomaly (hereby called alert pixel(s)) based on the NTI map produced. The pixels "surely" contaminated are detected by using an NTI threshold $\left(\mathrm{NTI}_{\text {tresh }}\right)$ which has been adapted to account for the seasonal variation of the background temperature of Stromboli (Fig. 2a). Whenever a pixel satisfy the following condition, $\mathrm{NTI}_{\mathrm{PIX}}>\mathrm{NTI}_{\text {thresh }}$, it is flagged as alert (surely). A closer inspection of the images however suggests that this condition fails to detect some small anomalies as occurred, for example, on February 20, 2006 (Fig. 2b). Therefore, in the case that any pixel satisfy the previous condition, the pixel having the maximum NTI within a $3 \times 3$ pixels box, around the summit (Fig. 2c) is considered as the most probable pixel potentially contaminated by a thermal anomaly, and is flagged as alert (potentially) as well.

\subsection{Step iv: Calculation of the apparent anomaly $\left(\Delta L_{4 S T R}\right)$}

Once one or more pixels are flagged as alert, the apparent anomaly at $4 \mu \mathrm{m}\left(\Delta \mathrm{L}_{4 \mathrm{STR}}\right)$ is calculated as:

$\Delta L_{4 S T R}=\sum_{1}^{\text {nalert }}\left(L_{4 a l e r t}-L_{4 b k}\right)$

where nalert is the number of alert, $\mathrm{L}_{4 a l e r t}$ is the $4 \mu \mathrm{m}$ radiance of the alerted pixel/s and $\mathrm{L}_{4 \mathrm{bk}}$ is the background radiance at $4 \mu \mathrm{m}$. This last, $\mathrm{L}_{4 \mathrm{bk}}$, is essentially controlled by the seasonal background temperature $\left(T_{b k}\right)$, and is generally calculated from the adjacent pixels (Giglio et al., 2003). We estimated $L_{4 b k}$ from the arithmetic mean of the 8 pixels surrounding the alerted one/s, which are not contaminated by clouds.
Following Giglio et al. (2003) night time pixels are flagged as cloudy if the single condition $\mathrm{BT}_{12}<265 \mathrm{~K}$ is satisfied, where $\mathrm{BT}_{12}$ is the brightness temperature at $12 \mu \mathrm{m}$ (MODIS band 32). The time series resulting from the calculation of $\Delta \mathrm{L}_{4 S T R}$ is illustrated in Fig. 3a.

3.5. Step v: Subtraction of the residual background and estimation of $L_{4 V O L C}$

In order to test the accuracy of this method we applied the steps $i$ to iv within an inactive area centred over Salina island, located $\sim 42 \mathrm{~km} \mathrm{SW}$ of Stromboli. The choice of Salina as a control target is justified by three main reasons: 1 ) the proximity of the two islands which allows the spectral radiances to be measured at the same time, with similar geometry conditions (satellite zenith and azimuth) and, for the most of the case, within the same MODIS granule; 2 ) the topographic resemblance between the summit area of Salina (Fossa delle Felci $961 \mathrm{~m}$ a.s.l.) and the summit of Stromboli (Pizzo sopra la Fossa-918 a.s.1.); 3) the climatic similarity between the two islands. We therefore calculate the $\Delta \mathrm{L}_{4 \mathrm{SAL}}$ in an identical manner as we made for Stromboli:

$\Delta L_{4 S A L}=\sum_{1}^{\text {nalert }}\left(L_{4 a l e r t}-L_{4 b k}\right)$

where nalert, $\mathrm{L}_{4 a l e r t}$ and $\mathrm{L}_{4 b \mathrm{~b}}$ are referred to the Salina mask.

As shown in Fig. 3b this method (steps $i$ to $i v$ ) produces a small apparent anomaly $\Delta \mathrm{L}_{4}$, also in absence of any thermal anomaly, as in the case of Salina island (Fig. 3b). This is likely due to the errors in estimating the $\mathrm{L}_{4 \mathrm{bk}}$ of the alerted pixel, from the pixels that are adjacent (see step $i v$ ), which, in the case of small and steep islands, such as Stromboli and Salina, are likely affected by an important topographic thermal gradient. (a)

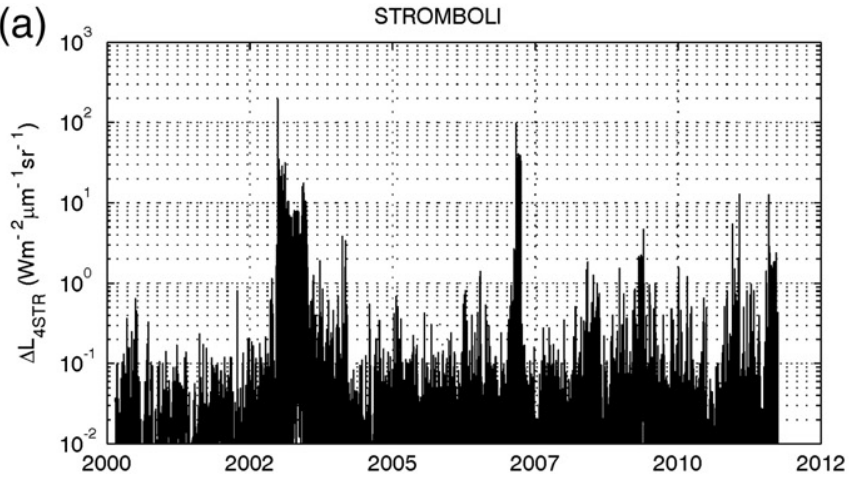

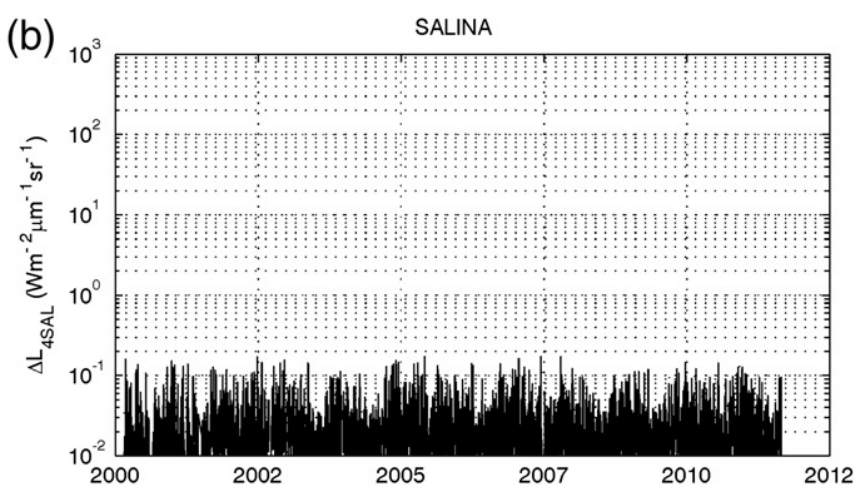

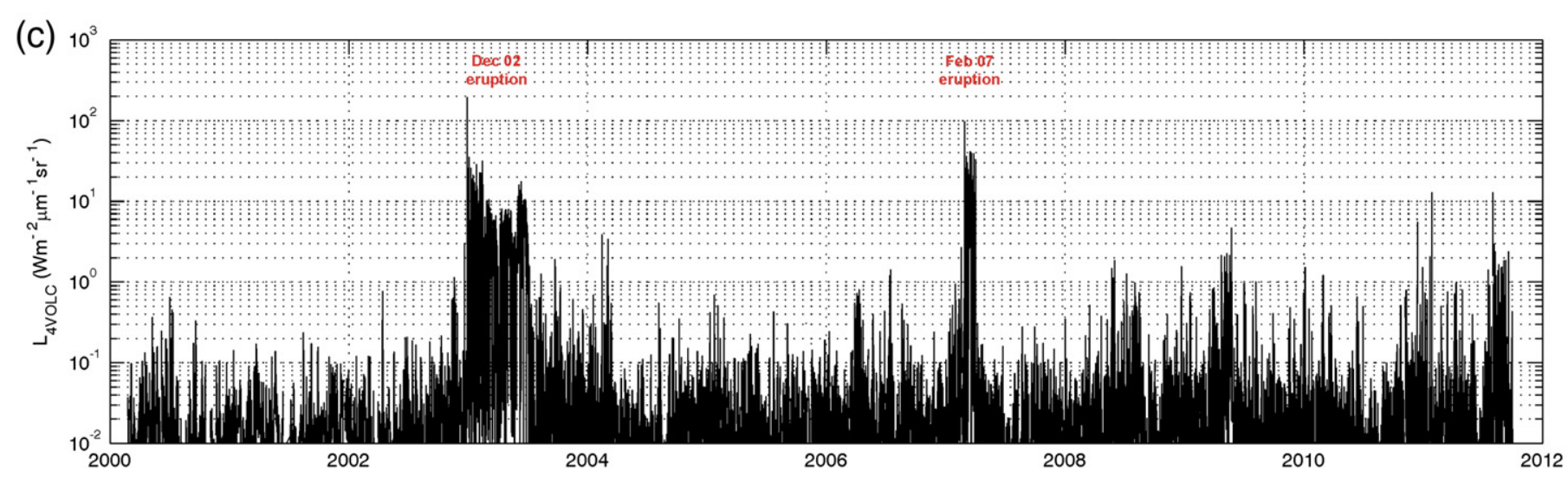

Fig. 3. Apparent anomaly $\Delta \mathrm{L}_{4}$ of Stromboli (a) and Salina (b). The net $4 \mu \mathrm{m}$ anomaly due to the volcanic activity of Stromboli ( $\mathrm{L}_{4 \mathrm{voLc}}$ ) is obtained from Eq. (2) (c). 
We therefore assume that the net $4 \mu \mathrm{m}$ radiance due to the strombolian activity (L $\mathrm{L}_{4 \mathrm{VOLC}}$; Fig. $3 \mathrm{c}$ ) can be calculated from $\Delta \mathrm{L}_{4 S T R}$ by subtracting this residual background, $\Delta \mathrm{L}_{4 \mathrm{SAL}}$, so that:

$L_{4 V O L C}=\Delta L_{4 S T R}-\Delta L_{4 S A L}$

\subsection{Step vi: Estimation of the volcanic radiative power (VRP)}

The radiative heat power produced by the volcanic activity (hereby defined as volcanic radiative power, VRP) can by calculated from the net spectral radiance at $4 \mu \mathrm{m}$ using the Wooster et al. (2003) equation:

$V R P=1.89 \times 10^{7} \times\left(L_{4 H}-L_{4 b k}\right)=1.89 \times 10^{7} \times L_{4 V O L C}$

where $\mathrm{L}_{4 \mathrm{H}}$ and $\mathrm{L}_{4 \mathrm{bk}}$ are the $4 \mu \mathrm{m}$ radiance of an hotspot-contaminated pixel and background pixel, respectively, which in our case correspond to the net $4 \mu \mathrm{m}$ spectral radiance produced by the volcanic activity $\left(\mathrm{L}_{4 \mathrm{VOLC}}\right)$. This equation is generally used for fire radiative power estimation (see Wooster et al., 2003 for details) and, as outlined by Wright and Pilger (2008), it is equally applicable to the analysis of volcanic activity allowing the estimation of VRP $( \pm 30 \%)$ when the target temperature is higher than $600 \mathrm{~K}$ (Wooster et al.,
2003). It follows that it is appropriate to calculate the heat radiated by the active portions of lava flows, or any other volcanic target having a temperature higher than $300^{\circ} \mathrm{C}$. This sensitivity suggests that small and cool objects will be almost "invisible" at $4 \mu \mathrm{m}$ thus producing a very low VRP. As it will be discussed in Section 7 this has some implication in the interpretation of VRP during the strombolian activity.

The volcanic radiative power resulting from Eq. (3) during 2000-2011 period is illustrated in Fig. 4a in a logarithmic scale (for graphical convenience).

\section{Rank-order plot}

A rank ordered statistical plot reveals that the whole dataset (8604 data) can be subdivided into three main groups (Fig. 4b). The main group is composed by the data having $\mathrm{VRP}<1 \mathrm{MW}$ and represents the $\sim 90 \%$ of the whole. These data are essentially related to the overpasses during cloudy conditions or under extreme viewing geometry that prevented the detection of any clear thermal anomaly. However, it is impossible to discriminate a small thermal anomaly within this group of data since it is shadowed by the noise of the signal. Therefore we prefer to apply a cut-off to $\mathrm{L}_{4 \mathrm{VoLC}}$ at $1 \mathrm{MW}$ to exclude these noisy data from further analysis.
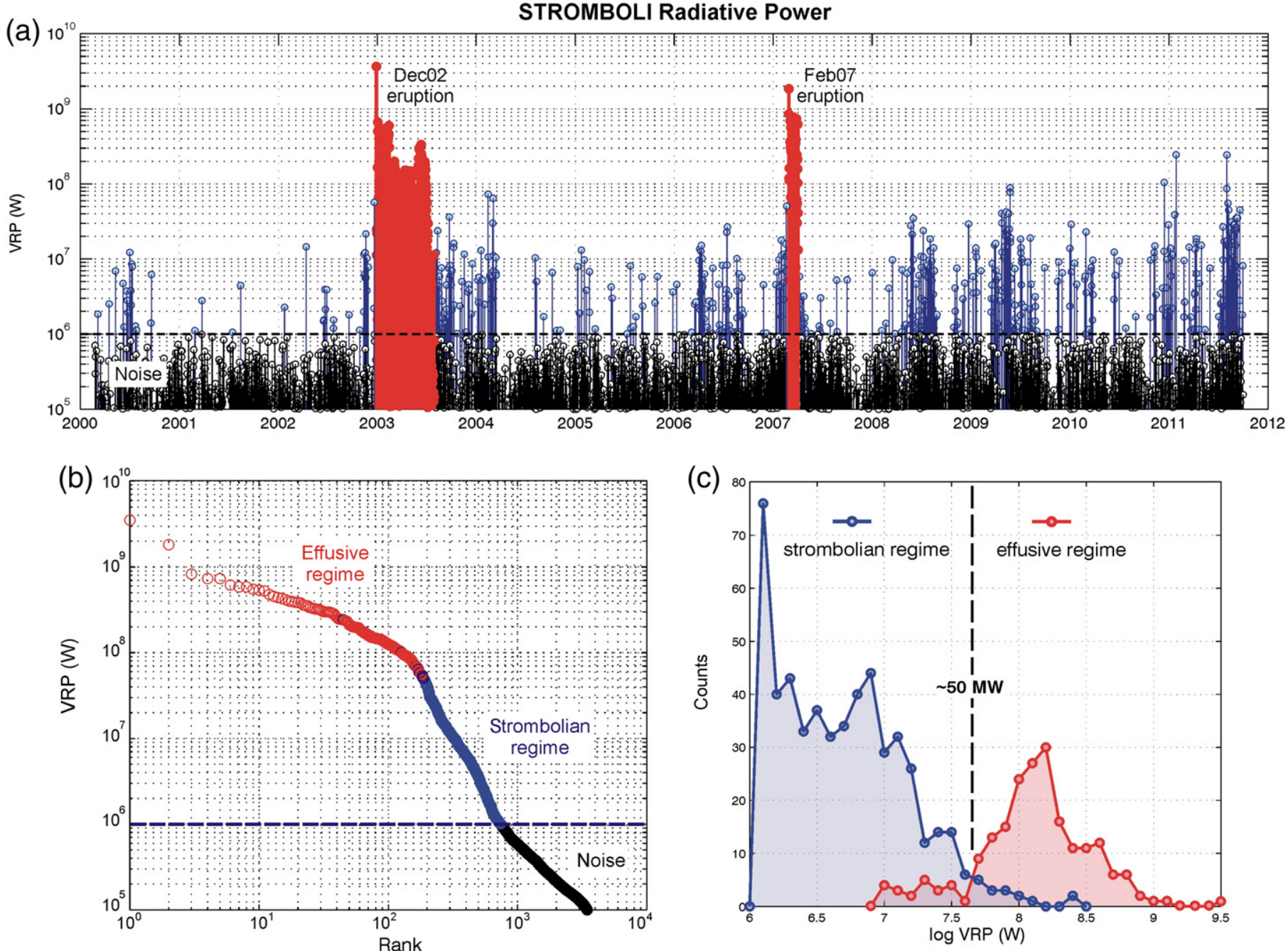

Fig. 4. (a) Rank order plot of VRP at Stromboli. Three main groups can be distinguished: a low level noise (black points), strombolian activity (blue points) and effusive activity (red points). (b) Frequency distribution of VRP related to the strombolian (blue) and effusive (red) regimes. A threshold at a 50 MW separates these two regimes. (For interpretation of the references to colour in this figure legend, the reader is referred to the web version of this article.) 
In addition, we conducted a visual inspection of the images acquired during the effusive eruptions in order to select only cloud free data. This is necessary since during the emplacement of lava flow clouds may partially mask the thermal anomaly, despite an alert is detected. In these cases the calculated VRP will be clearly underestimated and does not represent the real radiative power emitted by the whole lava surface.

Thus, the rest of the dataset (743) represents the genuine thermal anomalies detected during volcanic activity of Stromboli. These varied from $1 \mathrm{MW}$, during weak strombolian activity, up to more than $1000 \mathrm{MW}$, during the onset of the two effusive eruptions (28 December 2002 and 27 February 2007 in Fig. 4a) thus being comprised within three orders of magnitude.

In the rank-order log-log plot (Fig. 4b), a group of "events" (observations) of the same type should approximate a linear trend. Conversely, two distinct linear trends (such as those reported in Fig. $4 \mathrm{~b}$ ) represent a change in the nature of the phenomenon under scrutiny and are related to distinct types of volcanic activity (Rothery et al., 2001). A closer examination of the time series reveals that these two specific regimes of thermal radiation are associated to periods of "strombolian" and "effusive" activities, respectively, each one characterised by a given frequency distribution of VRP (Fig. 4c).

The strombolian regime (blue line in Fig. 4c) produces an VRP ranging from 1 to $244 \mathrm{MW}$, with an arithmetic mean of $\sim 9 \mathrm{MW}$ and with $98 \%$ of data having VRP $<50 \mathrm{MW}$. Conversely, the effusive eruptions (red line in Fig. 4c) are characterised by a VRP ranging from $8 \mathrm{MW}$ to $3500 \mathrm{MW}$ with an arithmetic mean of $\sim 186 \mathrm{MW}$. The tails of two distributions partially overlaps and intersect at a value of $\sim 50 \mathrm{MW}$ which represent a statistical threshold separating the two thermal regimes. As it will be discussed later, at Stromboli this threshold represent a transitional state between strombolian and effusive activity.

\section{Radiative power during the effusive activity}

The time series of the VRP recorded during the two effusive eruptions is shown in Fig. 5 where we used the same time scale for a direct comparison.

Both the two effusive eruptions showed an initial VRP higher than $1000 \mathrm{MW}$, which gradually decline over time producing a timeaveraged radiative power $\left(\mathrm{VRP}_{\text {ave }}\right.$ : calculated as the total radiated energy divided by the duration of the eruption) of $\sim 170$ and $388 \mathrm{MW}$ for the December 2002 and February 2007 eruption, respectively (Fig. 5). A specific discussion on the VRP trends in relation to the eruption chronology and activity is outside the purpose of this work. Instead, we want to focus on the empirical relationship between $\mathrm{VRP}_{\text {ave }}$ (for each eruption) and the related eruption rate ER (calculated as the total volume divided by the duration of the eruption). We therefore introduce a parameter, defined as $c_{\text {rad, }}$, that is calculated by dividing the mean radiative power by the eruption rate so that $\mathrm{c}_{\mathrm{rad}}=\mathrm{VRP}_{\text {ave }} / \mathrm{ER}$. Given an eruption rate of $\sim 0.7$ and $\sim 3.8 \mathrm{~m}^{3} \mathrm{~s}^{-1}$, for the two eruptions, we estimate $\mathrm{c}_{\mathrm{rad}} \sim 2.4 \times 10^{8} \mathrm{~J} \mathrm{~m}^{-3}$, for the December 2002 eruption, and $\sim 1.1 \times 10^{8} \mathrm{~J} \mathrm{~m}^{-3}$, for the February 2007 eruption. The different values of $c_{\text {rad }}$ obtained for the two events could arise from the errors in estimating VRP $( \pm 30 \%)$ as well as from different emplacement styles and local conditions which has characterised the two lava flows (cfr. Lodato et al., 2007; Calvari et al., 2005, 2010; Neri and Lanzafame, 2008; Marsella et al., 2009, in press). However these results suggest that, at Stromboli, a c $\mathrm{c}_{\text {rad }}$ equal to $1.75 \pm 0.65 \times 10^{8} \mathrm{Jm}^{-3}$ can be used to roughly convert a MODIS-derived VRP measurement into an estimate of the lava discharge rate $( \pm 40 \%)$ and vice versa.

It should be noted that by applying this coefficient to the VRP characterising the transition from strombolian to effusive activity (i.e. $50 \mathrm{MW}$, see previous chapter), we obtain a lava discharge rate of $0.33 \pm 0.12 \mathrm{~m}^{3} \mathrm{~s}^{-1}$. This is in excellent agreement with the (a) Dec 2002 Eruption

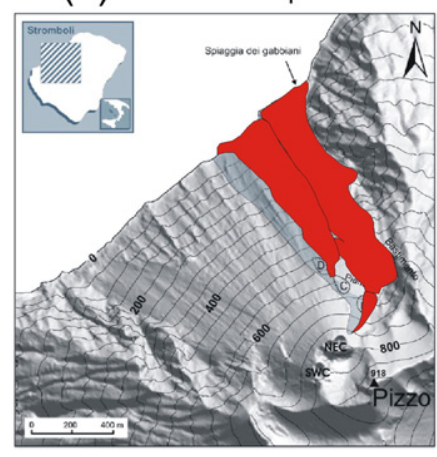

(b) Feb 2007 Eruption

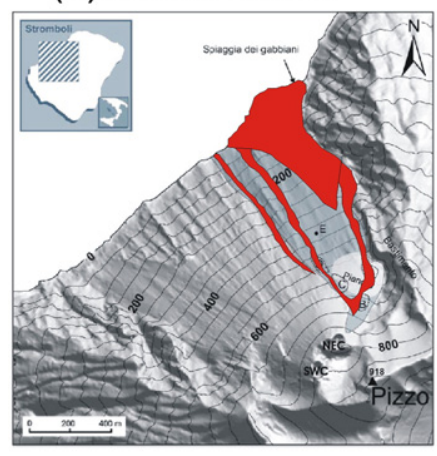

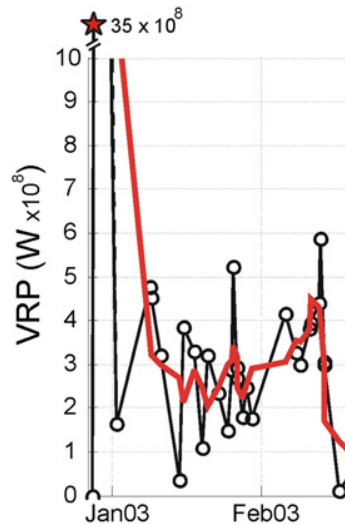

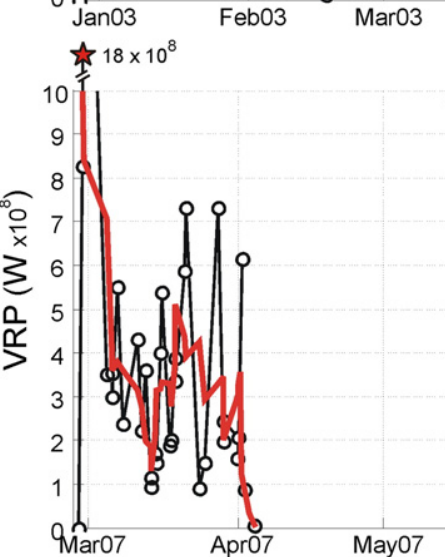

Time Averaged VRP $=170 \mathrm{MW}$

3 pts. mov.average

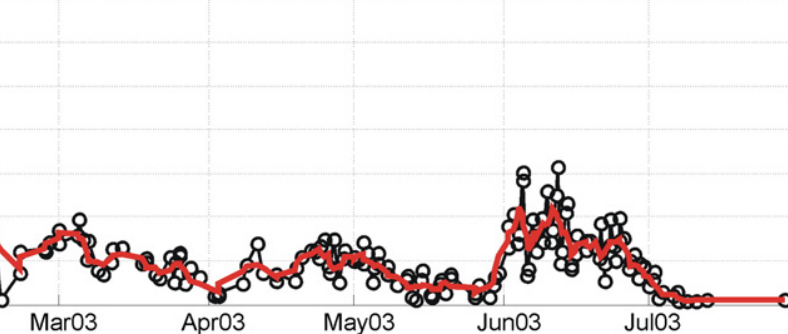

Time Averaged VRP $=388 \mathrm{MW}$

3 pts. mov.average

Fig. 5. Lava flow fields and volcanic radiative power (VRP) produced by the December 2002 eruption (a) and the February 2007 eruption (b). The Shaded relief map is modified from Landi et al. (2006). (For interpretation of the references to colour in this figure legend, the reader is referred to the web version of this article.) 
magma volume flux of $\sim 0.3 \mathrm{~m}^{3} \mathrm{~s}^{-1}$ at which a reverse transition, from effusive back to strombolian, has been observed during the 2002-2003 eruption (Ripepe et al., 2005).

\section{Frequency of alerted MODIS observations}

On a monthly scale, an important feature characterising the type of volcanic activity detected by MODIS is the frequency of the alerted MODIS observations $\left(f_{\text {ALERT }}\right)$, here defined as:

$f_{\mathrm{ALERT}}(m)=\frac{N_{\mathrm{ALERT}}(m)}{N_{\mathrm{OBS}}(m)}$

where $m$ is the month considered, $\mathrm{N}_{\mathrm{ALERT}}(m)$ and $\mathrm{N}_{\mathrm{OBS}}(m)$ are the number of alerted overpasses and total number of MODIS observations (overpasses) during the month $m$, respectively. The use of this parameter allows us to normalise the frequency of observations during period when only one satellite was functioning such as during February 2000 to May 2002 when only the EOS-Terra platform was operational.

Instead of being sensitive to the "intensity" of the thermal anomaly (as VRP), this parameter is essentially controlled by its temporal "persistence", assumed to be $100 \%$ during a continuous effusion of lava lasting at least one month. Consequently, during an effusive eruption, $f_{\text {ALERT }}$ it is solely affected by the frequency of heavy cloudy days that completely masked the hotspot.

During the 7 months of continuous lava effusion (January-June 2003 and February 2007) we found $f_{\text {ALERT }}$ spanning from $~ 50 \%$ to $\sim 95 \%$, with an average value of $\sim 65 \%$ (Fig. 6a). This suggests that over these eruptive periods, an average of $35 \%$ of the overpasses was masked by clouds. Note that the increase of $f_{\text {ALERT }}$ from January 2003 to June 2003 likely reflects different cloudy conditions, typical of cold and hot seasons, thus suggesting that clouds may prevent the alert detection on $50 \%$ of the overpasses in the winter season, and only $5 \%$ during the summer. However, we may state that despite the season, during an effusive eruption of Stromboli at least half of monthly MODIS overpasses should detect a thermal anomaly.
Therefore, in addition to the VRP, an $f_{\text {ALERT }}$ of $50 \%$ can be used to discriminate the months characterised by a continuous effusive activity from the months characterised by a different type of volcanic activity.

During the typical strombolian regime, $f_{\text {ALERT }}$ ranged from 0 to $45 \%$ with an average value of $\sim 6 \%$ (Fig. 6a) which is about one tenth of those measured during effusive activity $(\sim 65 \%)$. This implies that the average "persistence" of the thermal anomaly associated to noneffusive activity is at least $\sim 1.5 \mathrm{~h}$ per day. This is somehow consistent with the occurrence of intermittent strombolian explosions, with an average explosion rate of $\sim 13$ events/h (Ripepe et al., 2008) with a mean duration of $15 \mathrm{~s}$ (Patrick et al., 2007) that makes nearly $1.3 \mathrm{~h} /$ day (or $\sim 5,5 \%$ of time) occupied by the related thermal anomalies. However, in our dataset, the frequency of alerted MODIS observations recorded during the strombolian regime shows clear fluctuations, with several periods characterised by a value up to $15-45 \%$ (Fig. 6a). Therefore, during these months a thermal anomaly persisted in the crater area for more than $4-10 \mathrm{~h} / \mathrm{day}$. In the next chapter, we will show that this high persistence of a thermal anomaly has a direct connection with the interpretation of the radiative power measured during the strombolian regime.

\section{The source of the radiative power during strombolian activity}

While during effusive periods the high VRP $\left(10^{8}-10^{9} \mathrm{~W}\right)$ is produced by the radiating surface of active lava flows, the source of the heat detected during the strombolian regime $\left(10^{6}-10^{8} \mathrm{~W}\right)$ may be associated essentially to three main thermal sources present within the crater area of Stromboli. These are: the explosions, the material ejected during the explosions and cooling within the crater area, and the active vents.

Strombolian explosions are intermittent phenomena having, at Stromboli, an average frequency of 13 event/h (Ripepe et al., 2008) and mean duration of $15 \mathrm{~s}$ (Patrick et al., 2007). However it has been commonly observed that, their frequency is variable on a time scale of hours to month (Ripepe et al., 2002), thus they have a
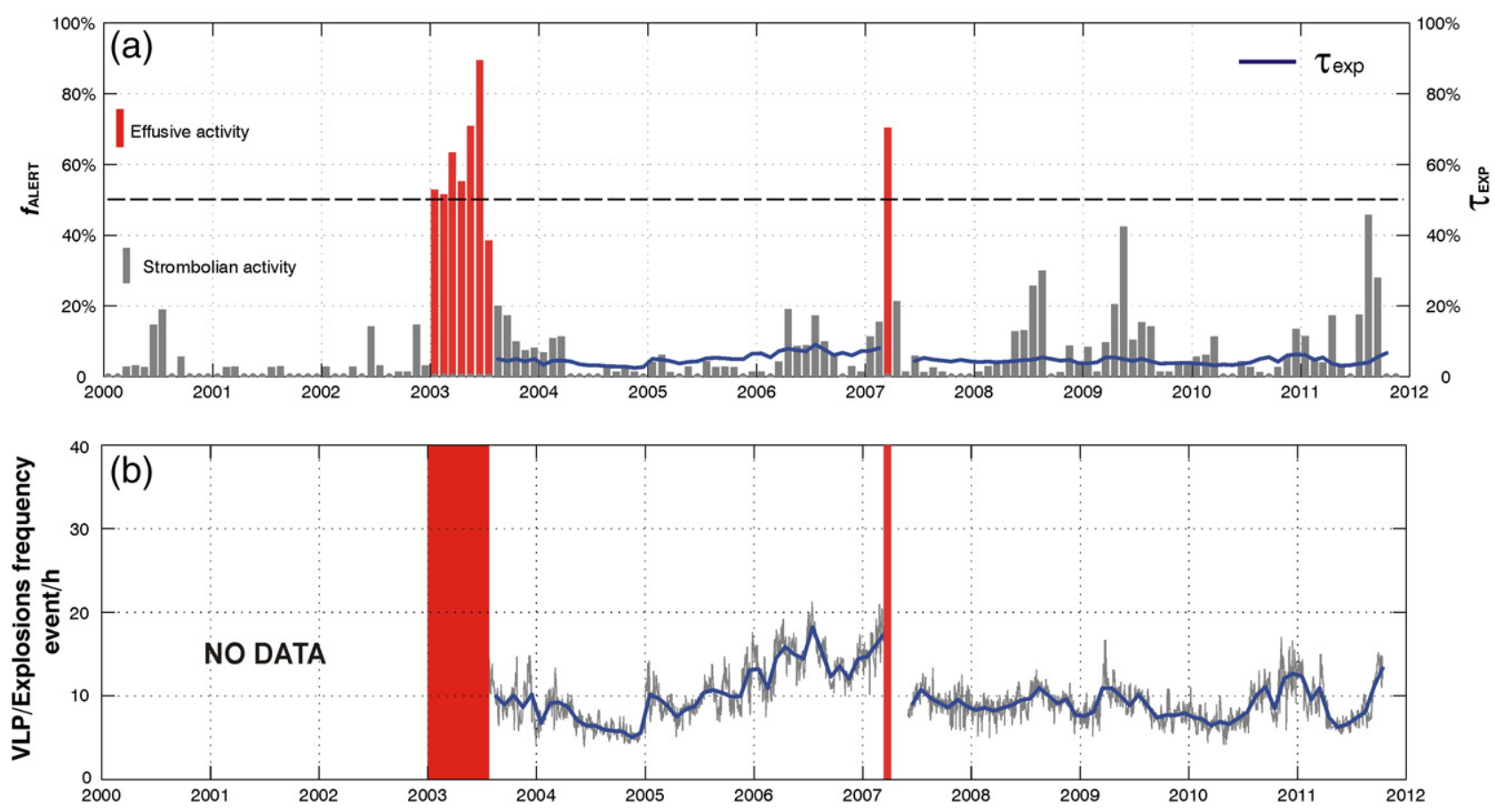

Fig. 6. (a) Frequency of alerted MODIS observations $f_{\text {ALERT }}$ during effusive activity (red bar) and strombolian activity (grey bar); the blue line represent the temporal persistence of a thermal anomaly associated to the strombolian explosions ( $\tau_{\exp }$ ) according to their frequency (as shown in b) and an average duration of $15 \mathrm{~s}$ (Patrick et al., 2007 ); (b) frequency of VLP-explosion recorded at Stromboli between 2003 and 2011 (Laboratorio di Geofisica Sperimentale, University of Florence, Italy). (For interpretation of the references to colour in this figure legend, the reader is referred to the web version of this article.) 
primary role in modulating the persistence of the associated thermal anomaly. The explosion rate effectively affects the probability that a MODIS overpass detect the explosions themselves so that during frequent strombolian explosions we may expect an increasing number of MODIS alerts (high $f_{\text {ALERT }}$ ).

In order to show this correlation, we define the monthly persistence of a thermal anomaly associated to strombolian explosions $\left(\tau_{\exp }\right)$ as:

$\bar{\tau}_{\text {exp }}(m)=\frac{\bar{N}_{\text {exp }}(m) \times t_{\text {exp }}}{t_{\text {month }}(m)}$

where $m$ is the month considered, $N_{\text {exp }}$ is the number of explosion that occurred during the month $m, t_{\exp }$ is the average duration of each explosion (in seconds) and $t_{\text {month }}(m)$ is duration of the month $m$ (in second). As a proxy of the number of explosions occurred at Stromboli we used the number of VLP events measured by the Laboratorio di Geofisica Sperimentale (University of Florence, Italy) during 2003-2011 (Fig. 6b). Very long period (VLP) events are generally associated with the explosive processes (Neuberg et al., 1994; Ripepe et al., 2001; Chouet et al., 2003). Therefore, the rate of occurrence of VLP events is here considered synonymous with rates of strombolian explosions $\left(N_{\exp }\right)$ and is shown in Fig. 6b. A general correlation may be qualitatively inferred by comparing the trends of $f_{\text {ALERT }}$ (Fig. 6a) and $N_{\exp }$ (Fig. 6b), with periods of higher explosion frequency marked by increased number of MODIS alerts. However, by assuming the average explosion's duration typically observed at Stromboli (15s), the calculated $\tau_{\exp }$ ranges from $2.5 \%$ during weak explosive activity up to a maximum of $\sim 9 \%$ during the periods of very high explosion rates (blue line in Fig. 6a). In these periods (i.e. 2004, 2006, 2008, 2009, 2011) the frequency of MODIS alerts suggests a more persistent thermal anomaly present in the crater area $\left(f_{\text {ALERT }}=10-45 \%\right)$, clearly higher than the one produced exclusively by the strombolian explosions themselves (despite their very high frequency). Therefore it is rather unlikely that explosions are the unique source of the thermal anomalies detected in these periods.

A further indication that explosions alone could not have produced the VRP measured in the above periods, is given from field estimates of the thermal energy typically radiated by a single strombolian explosion. Marchetti et al., 2009 found that, at Stromboli, the explosions radiate an average of $2.4 \mathrm{MJ}$ with maximum value as high as 8.4 MJ. By considering the average duration of $15 \mathrm{~s}$ this energy is produced by a time-averaged radiative flux of $\sim 0.56 \mathrm{MW}$. Since during a single explosion the peak value (at the climax of the explosion) may be much higher than these time-averaged values we may assume that the maximum radiant flux is one order of magnitude higher, that is $5-10 \mathrm{MW}$ for the most energetic cases. This is probably the upper limit that the MODIS may detect if the heat radiated during the strombolian regime was solely related to distinct and intermittent explosions. Conversely, during the periods of high $f_{\text {ALERT }}$ (i.e. more than $10 \%$ ) a large number of alerts were characterised by a VRP higher than $10 \mathrm{MW}$ (Fig. 4), which once more cannot be explained by the explosions themselves.

Material ejected during the explosions (bombs, scoriae, lapilli and ash) and accumulated within the crater terrace may represent a further source of thermal anomaly. However, due to the fast cooling of such fragmented material it is unlikely that a VRP of $10 \mathrm{MW}$ will be radiated by these objects. Note that, by assuming the whole crater terrace $\left(\sim 20,000 \mathrm{~m}^{2}\right)$ completely filled by scoriae at $150^{\circ}$ a theoretical MODIS pixel should detect only $\sim 0.5 \mathrm{Wm}^{-2} \mu \mathrm{m}^{-1} \mathrm{sr}^{-1}$ at $4 \mu \mathrm{m}$, or approximatively a VRP of 2 MW (by means of Eq. (3)). Therefore we may exclude that the accumulation of such fragmented material would give such a high and persistent radiative power. Nevertheless, we may not rule out that the detection of low VRP (i.e. $<10 \mathrm{MW}$ ) could be originated by this cooling material as well as by the concomitance of a strombolian explosion with a MODIS overpass.
Vents represent the most persistent source of thermal anomaly which may fluctuate in intensity over time. Previous measurements of the heat radiated by Stromboli (Harris and Stevenson, 1997a, 1997b) used AVHRR data to show that a variable radiative power was associated to different levels of activity (e.g. in 1985-1986 and 1990-1994 periods). In particular, about 0.2 MW was measured during very mild activity, whereas $\sim 9 \mathrm{MW}$ was measured during periods of higher activity. However in their analysis Harris and Stevenson (1997a) reported that when lava activity was observed within the crater terrace, the saturation of the AVHRR channel 3 (centred at $3.7 \mu \mathrm{m}$ ) inhibited the estimation of the radiative power. This occurred on 14 of the 34 analysed images ( $41 \%$ of the AVHRR overpasses) thus indicating that such kind of activity produced a radiative output surely higher than $9 \mathrm{MW}$. Note that during a phase of a low-moderate explosive activity (6 explosions/h) Harris and Stevenson (1997a) estimated that $\sim 2$ MW were radiated by 5 active vents having an integrated temperature range of $250-480{ }^{\circ} \mathrm{C}$ and a total vent area of $330 \mathrm{~m}^{2}$. Supposing that during a much more intense phases of activity, the magma column may rise up to free surface and completely fill this vent area $\left(330 \mathrm{~m}^{2}\right)$, approximatively $47 \mathrm{MW}$ should be radiated (assuming a lava temperature of $1000^{\circ} \mathrm{C}$ and emissivity of 0.95). This condition seems to explain the high values recorded by MODIS as well as the recurrent saturated values of AVHRR data.

As we have seen previously a radiative power of $\sim 50 \mathrm{MW}$ represents also the transition between strombolian and effusive regimes which likely occur when the magma column has reached the free surface. Notably this condition takes place when the rate of magma supplied at depth, and degassing within the feeding system (typically $0.3 \mathrm{~m}^{3} \mathrm{~s}^{-1}$ at Stromboli; Allard et al., 1994), is balanced by an equal amount of lava discharged at the vents. Therefore, a VRP of $50 \mathrm{MW}$ is a remarkable threshold below which the feeding system approaches the behaviour of a lava lake where most of the degassed magma is cycled back within the conduit. In such condition a radiant power of $<50 \mathrm{MW}$ represent the thermal output produced by a magma column fluctuating in the upper part of the shallow conduit, which in turn may cause a variable amount of lava to be exposed in the vent area. The fact that all the periods characterised by recurrent VRP comprised between 10 and $50 \mathrm{MW}$ are accompanied by a high explosion's rate (cfr. Figs. 3a and 6a) it is also consistent with a higher magma column feeding the more frequent strombolian explosions at the surface.

Conversely a VRP higher than $50 \mathrm{MW}$ is representative of a volume flux $\left(>0.3 \mathrm{~m}^{3} \mathrm{~s}^{-1}\right)$ which cannot be contained within Stromboli's shallow conduit geometry. This is consistent with the three highest VRP measurements (>100 MW) recorded during the strombolian regime, that were coeval with major episodes of sustained spattering/ fountaining, which fed intracrater lava flows as well as major lava outflows down the Sciara del Fuoco (see Table 1).

Thus we suggest that the radiative power detected during the strombolian regime is not directly related to the explosion rate itself, but rather to the fluctuation of the magma level within the conduit which eventually led to episodes of sustained spattering, fountaining and outflows.

\section{Monthly averaged radiative power (VRPm)}

In the previous chapters we have seen that single measurements of VRP and the monthly frequency of alerted overpasses ( $f_{\text {ALERT }}$ ) allow us to discriminate between effusive and strombolian regimes and give us the opportunity to estimate how intense and persistent is the thermal anomaly produced by the volcanic activity. In order to combine these two information, we calculate the monthly averaged radiative power (VRPm), by assigning a value equal to 0 to any overpasses which falls below the noise threshold (VRP $<1 \mathrm{MW}$, see Section 4), and including these in the monthly average. By including the below-noise values as zero the resulting average value will effectively incorporate the frequency of alerts as well as their magnitude. 
Table 1

Chronology of observations that were accompanied by a VRP $>50 \mathrm{MW}$. A brief description of the activity in the crater area is also reported. In bold are outlined the dates when a VRP $>100$ MW has been detected, that are coeval with major episodes of spattering and lava overflows. These data are represented by stars in Fig. 6.

\begin{tabular}{|c|c|c|c|}
\hline Period & Date & MW & Reported activity \\
\hline 2000-2004 & 20-Dec-2002 20:25:00 & 56.9 & $\begin{array}{l}\text { Very high strombolian activity and magma level close to the crater } \\
\text { rim on late December } 2002 \text { (Calvari et al., 2005; Burton et al., 2008). }\end{array}$ \\
\hline \multirow[t]{3}{*}{ 2004-2008 } & 14-Feb-2004 01:50:00 & 72.9 & Activity at Stromboli's three summit craters increased between \\
\hline & 04-Mar-2004 00:40:00 & 64.3 & $\begin{array}{l}10 \text { February and } 8 \text { March, leading to significant growth of spattern } \\
\text { cones inside the craters. (Smithsonian Institute, 2004). }\end{array}$ \\
\hline & 17-Feb-2007 $20: 25: 00$ & 50.7 & $\begin{array}{l}\text { Sharp increase of tremor amplitude, infrasonic pressure and explosion } \\
\text { rate since February 15, } 2007 \text { (Ripepe et al., 2009). }\end{array}$ \\
\hline \multirow[t]{7}{*}{$2008-2012$} & 23-May-2009 21:00:00 & 77.0 & Remarkable high activity in April-May and 2009 with several intracrater \\
\hline & 24-May-2009 01:20:00 & 88.7 & lava flows (Smithsonian Institute, 2010). \\
\hline & 14-Dec-2010 01:10:00 & 104.6 & $\begin{array}{l}\text { Intense spattering activity on Dec } 14,2010 \text { between 00:30 and 02:30. } \\
\text { (INGV Report, 2010). Possible lava flow on Sciara del Fuoco. }\end{array}$ \\
\hline & 26-Jan-2011 21:20:00 & 244.5 & $\begin{array}{l}\text { Intense spattering and fountaining activity on 25-26 Jan 2011. Intra crater } \\
\text { lava flow since } 20: 50 \text { on Jan, } 26 \text { (INGV Report, 2011a) }\end{array}$ \\
\hline & 01-Aug-2011 $21: 00: 00$ & 86.5 & Intense spattering and overflow along the Sciara del Fuoco from Aug 1st, \\
\hline & 02-Aug-2011 $01: 15: 00$ & 243.1 & at $20: 56$ to Aug 2 nd at $05: 10$. Lava volume: $0.04 \mathrm{Mm}^{3}$. Eruption rate: $0.7 \mathrm{~m}^{3} \mathrm{~s}^{-1}$ \\
\hline & 06-Aug-2011 00:50:00 & 55.2 & (INGV Report, 2011b). Explosive sequence on August 5. \\
\hline
\end{tabular}

The calculated VRPm is thus considered as a proxy of the mean radiant power produced by the volcanic activity occurred in 1 month (Fig. 7). This is a minimum estimate since it does not take into account the heat radiated below the background as well as the presence of clouds which may have masked the thermal anomalies on $5-45 \%$ of cases. However, during 12 year analysis the amplitude of the variations in VRPm values (2-5 orders of magnitude Fig. 6) clearly overcomes the above factors so that the trend drawn in Fig. 7 closely reflects the main fluctuations of the radiative thermal output occurred at Stromboli between 2000 and 2011. As it will be discussed in the next chapter we suggest that these fluctuations can be ascribed to the monthly variations of the magma level feeding the strombolian activity at the surface.

\section{Discussion}

Recent studies have shown that months preceding the last effusive eruptions were characterised by the rise of the magma within the conduit, accompanied by a gradual increase of explosive activity and several geophysical and geochemical parameters (Ripepe et al., 2005; Burton et al., 2008; Aiuppa et al., 2009; Ripepe et al., 2009; Rizzo et al., 2009). These trends are confirmed by our MODISderived data which are summarised in Fig. 7. For example a sharp raise of VRPm occurred from October $2002(<0.1 \mathrm{MW})$ to November and December $2002(\sim 1 \mathrm{MW})$. Importantly a single VRP of $\sim 57 \mathrm{MW}$ was detected on 20 December 2002 at 20:25 (star in Fig. 7), that is 8 days before the onset of the 2002 eruption. Such high radiant power suggests that 1 week before the beginning of the effusion, the magma column was completely exposed at the free surface and that, at that time, the feeding system had reached its maximum capability to contain the upcoming magma flux. A similar trend was also recorded before the 2007 eruption. In this case the VRPm increased from less than 0.1 MW, in December 2006 up to $~ 2 \mathrm{MW}$ in February 2007 and culminated with a VRP value of $\sim 51 \mathrm{MW}$ recorded on 17 February 2007 at 20:25, or 10 days before the onset of the 2007 eruption (star in Fig. 7b).

The analysis of these two key periods clearly defines a common pattern before the last effusive eruptions, with an increasing radiative power during the previous 2 months up the detection of more than $50 \mathrm{MW}, 8-10$ days before the onset of the effusions. This proves that the MODIS data can track the rise of the magma level up to a common threshold above which the transition into an effusive activity occurred.

Nevertheless, a similar trend (characterised by an increasing phase lasting 1-3 months and culminating in at least one detection at VRP $>50 \mathrm{MW}$; stars in Fig. 7) has been detected during four other periods of major activity, which however did not evolve into an effusive flank eruption. This occurred on January-February 2004 , March-May 2009, November 2010-January 2011 and July-August 2011. During these periods field observations reported that the activity was somehow unusual or at the higher limit commonly observed (see Table 1), with several episodes of sustained spattering, fountaining and recurrent lava outflows. In these cases the trend drawn by the VRP is consistent with a general increase of the magma level up to the free surface as well.

The reasons why not all the increases of the thermal output lead to a major effusive phase is unclear and needs further investigations. One possibility is that the MODIS data have no sufficient temporal resolution, to detect fast and pronounced changes on the summit activity, which could eventually produce a VRP $>50 \mathrm{MW}$ in the hours preceding an effusive eruption. In this case, the maximum VRP recorded during the strombolian regime (i.e. $244 \mathrm{MW}$ on August 1, 2011; Table 1) could reflect the radiative power emitted by an higher magma flux which cannot be confined within the shallow plumbing system (vented by the summit overflows) but is still insufficient to cause the lateral failure of the conduit walls. However we may not exclude that a high magma level is a condition necessary but not sufficient to signal the upcoming effusive flank eruption.

The main control on magma levels, is the reservoir pressure and the density contrast between magma and host rocks. Since there were no evidence of a change in magma density before the 2002 eruption Burton et al. (2008) ascribe the rising of the magma column, observed in September-December 2002, to an increase in the magma pressure within the feeding system of Stromboli. Accordingly, if we assume that the density contrast between the magma and host rocks remained unchanged between 2000 and 2011, we may relate all the observed fluctuations of radiative power to cyclic pressurisation phases of the magma column within the feeding system. Ripepe et al. (2002) suggest that cyclic variations in the rate at which the shallow system of Stromboli is supplied by gas-rich magma, produce fluctuations in degassing and explosive activity on a time scale of minutes or hours. If the same mechanism is effective at longer time scales, these high frequency fluctuations could be overprinted on cycles of magma supply with longer periods (i.e. some months), as for example proposed to explain pulsating effusion rates varying on time scales of minutes to months at Mt. Etna; Harris and Neri, 2002; Lautze et al., 2004. Note that a slight pulsating effusion rate characterises also the 2002 eruption of Stromboli (Fig. 4), where at least four distinct cycles, lasting 1-2 months each, are overlying a general declining trend as also observed by Lodato et al. (2007).

On the other hand if we assume that the density contrast between magma and host rocks may have changed cyclically throughout the analysed period, it is possible that some of the observed fluctuations were not simply associated to the variation of the magma supply 
STROMBOLI Radiative Power
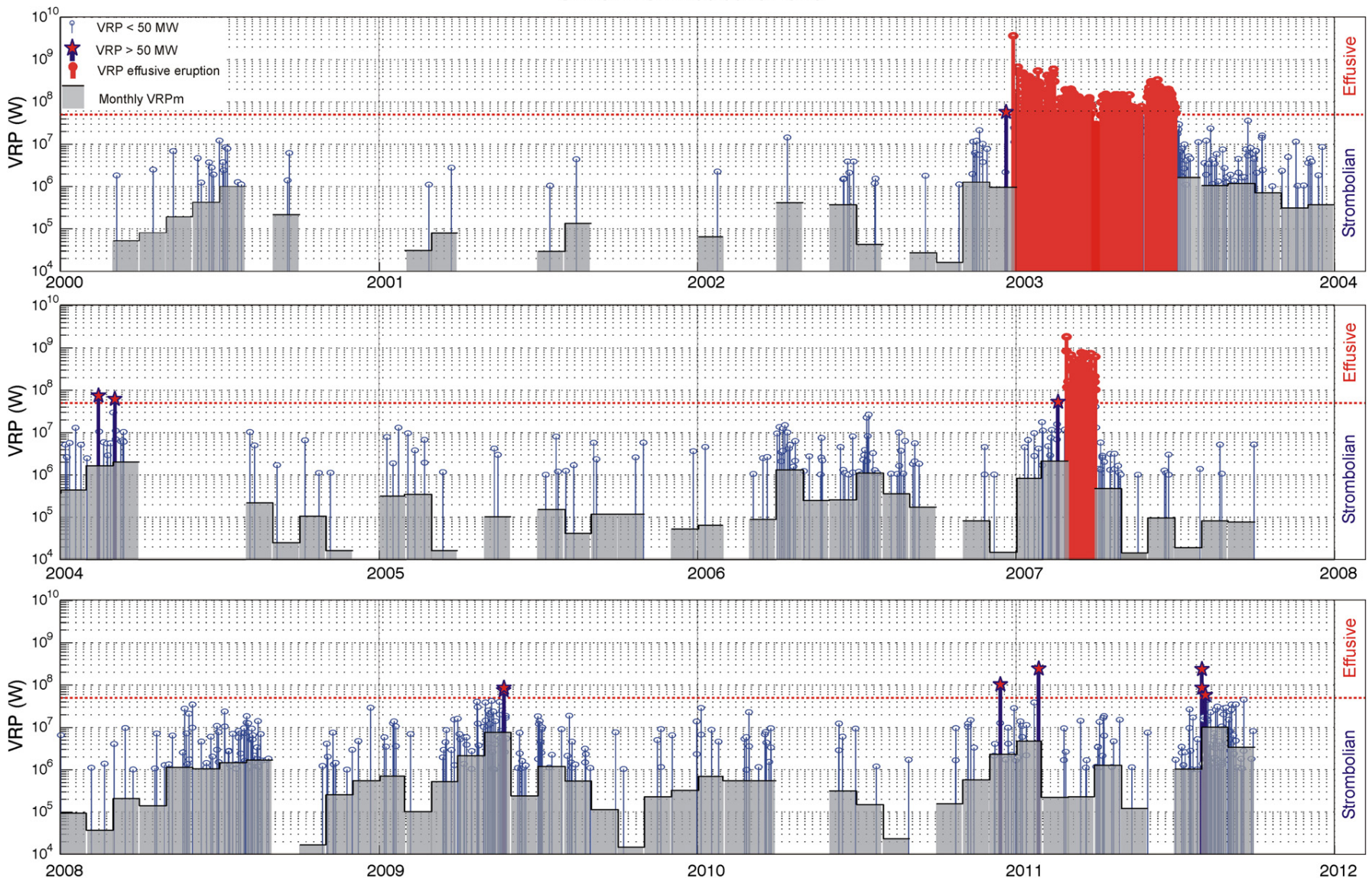

Fig. 7. Detailed time series of the radiative power (on logarithmic scale) at Stromboli between 2000 and 2011. Grey bars refer to the monthly average values (VRPm) while stems refer to single VRP measurements. Star stems correspond to detection of VRP $>50 \mathrm{MW}$, as reported in Table 1, while red stems correspond to VRP detected during the two effusive eruptions. The red line represent the threshold ( $50 \mathrm{MW}$ ) at which the transition between strombolian and effusive activity occurs. Note the fluctuations of VRPm which we ascribe to the monthly variations of the magma column feeding the activity at the surface. A general increase in the frequency and intensity of these fluctuations is visible since 2008. (For interpretation of the references to colour in this figure legend, the reader is referred to the web version of this article.) 
(or magma pressure). Lautze and Houghton $(2005,2007)$ propose that continual changes in shallow melt rheology and density of Stromboli magma have a strong influence on the monthly scale pattern of strombolian activity. A similar mechanism was also proposed to explain convective overturn of magma in the shallow conduit or within a lava lake which may occur within minutes (Harris et al. 2005) to years or decades (Rymer et al., 1998). Witham et al. (2006) demonstrated that an evolving magma density within the conduit it is able to reproduce spontaneous cycles of filling and emptying of lava lakes without changes in the reservoir pressure.

Noticeably the frequency of the fluctuations of VRPm as well as their intensity has clearly increased since 2008 (Fig. 7). This is evident by plotting the cumulative energy radiated by the strombolian activity (i.e. $\sim 1.8 \times 10^{14} \mathrm{~J}$, calculated by integrating the VRPm over the 12 analysed years) in which we may note an evident change in the slope since 2008, being consistent with an overall increase in the radiative emission (hence magma column height) after the 2007 eruption (Fig. 8). Since both the reservoir pressure and the density contrast, control the height of the magma column our results suggest that the February 2007 eruption may have perturbed in some way, some of these parameters. The frequently high magmatic column observed since 2008 could therefore result by a general increase of the overpressure within the conduit and/or by an overall increase in the density contrast between magma and host rocks which followed the 2007 eruption. Note that differently from the previous effusive phase, the 2007 eruption has been characterised by a major collapse of the summit area (1-2 $\mathrm{Mm}^{3}$; Neri and Lanzafame, 2008) that have perturbed the shallow plumbing system and the stress field around the conduit, much more pervasively than 2002 eruption.

Nevertheless our data suggest that the strombolian activity during 2000-2011 has been fed by a magma column oscillating at shallows levels on a time scale of several months. If these fluctuations are related to cyclic pressurisation of the feeding system or to recurrent overturn caused by evolving magma density contrast, is still an open question. However the integration of MODIS data with other geophysical and geochemical dataset will possibly help to understand these key issues.

\section{Conclusions}

The analysis of MODIS night-time data over Stromboli has been used to estimate the heat radiated during 2000-2011, and allowed us to detect and characterise changes in the activity of the volcano. By using the $4 \mu \mathrm{m}$ radiance and an accurate characterisation of the background signal, we were able to define two main regimes of volcanic radiative power (VRP) at Stromboli:

i) a high radiating regime, associated to "effusive activity" and characterised by a VRP ranging from 8 to $3500 \mathrm{MW}$ with a mean of $~ 186 \mathrm{MW}$;

ii) a low radiating regimes, associated to "strombolian activity" and characterised by VRP ranging from 1 to $244 \mathrm{MW}$ with a mean of $\sim 9 \mathrm{MW}$.

These two regimes are separated by a transitional threshold of $\sim 50 \mathrm{MW}$ which correspond to the exposure of magma at the surface, at the same rate in which gas-rich magma normally ascends and degasses $\left(\sim 0.3 \mathrm{~m}^{3} / \mathrm{s}\right)$ within the shallow plumbing system.

We suggest that above this threshold a transition from strombolian to effusive activity takes place, and may lead the occurrence of major flank eruptions or minor outflows from the summit crater. On the contrary a $\mathrm{VRP}<50 \mathrm{MW}$ is related to a magma column at shallower levels, so that the feeding system behaves like a lava lake where a portion of the degassed magma is cycled back and fed the typical strombolian activity.

In addition to the effusive eruptions, the activity of Stromboli between 2000 and 2011 has been characterised by long-period fluctuations of the radiative power which are interpreted in terms of recurrent rises and falls of the magma column at monthly scale. The rise of the magma column was observed before both the effusive eruptions with an increasing activity lasting 1-2 months and reaching the threshold of $50 \mathrm{MW}, 8-10$ days before the onset of the effusion. This threshold was also reached and/or exceeded during few other periods of activity which however were not followed by a major eruption, but only by summit overflows. Significantly these phenomena

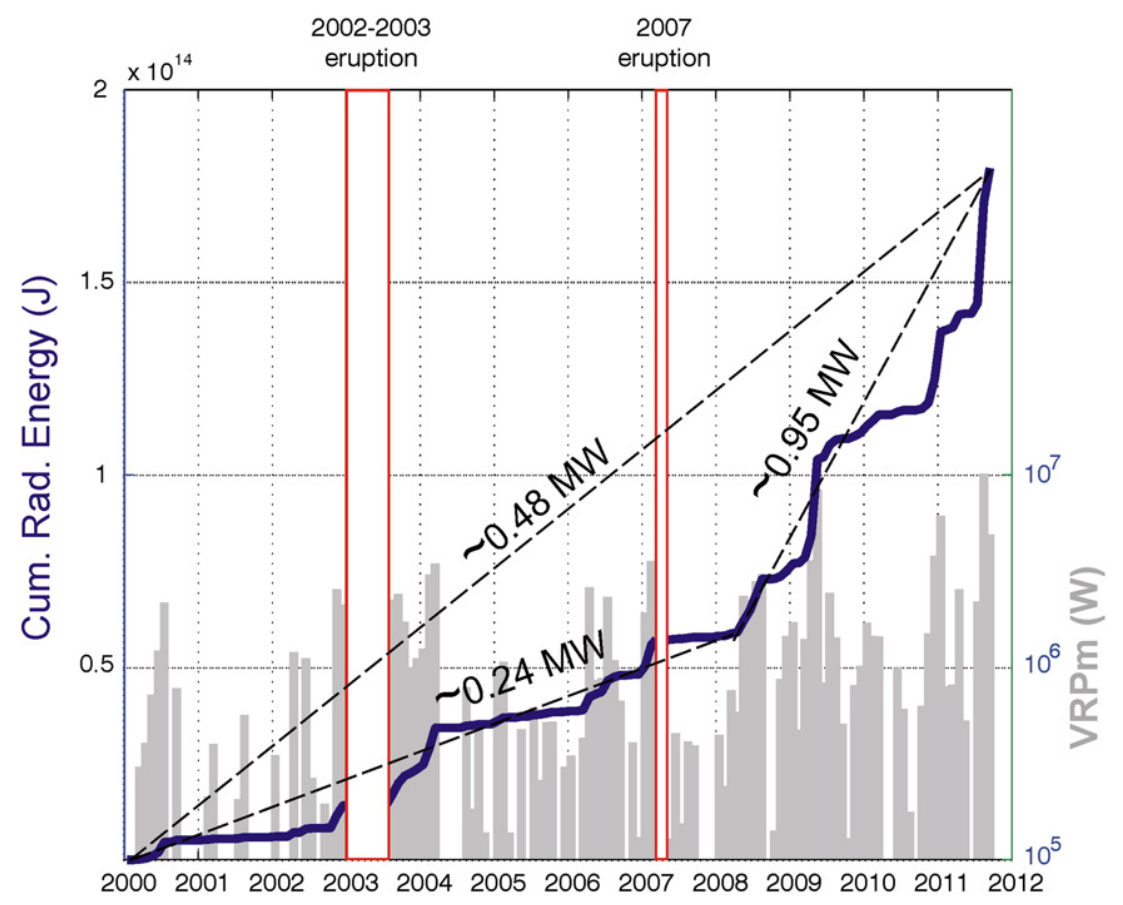

Fig. 8. Cumulative radiative energy (left axis) and monthly averaged VRPm (right axis) emitted by the strombolian activity from 2000 to 2011 (the two effusive periods are excluded). Note the sharp increase of the energy radiated since 2008 (shown by the higher slope of the trend line). 
occurred more frequently after the 2007 eruption and suggest that this event has perturbed the shallow plumbing system feeding the current activity at the surface. Nonetheless we suggest that, the detection of a radiative power higher than $50 \mathrm{MW}$ is a clear evidence of a high magma level in the conduit of Stromboli, which will have implication for the levels of activity and hazard posed.

In conclusion we propose that the MODIS data can be processed automatically, together with other datasets (e.g. seismicity, explosion counts, infrasonic pressure) to monitor the thermal output of Stromboli volcano and give us an additional parameter to predict the onset of an effusive eruption.

\section{Acknowledgements}

This research was funded by the Italian Ministry for Universities and Research (MIUR). D. Piscopo's work was funded by the Lagrange Project and supported by the CRT Foundation. We thank Robert Wright and Matthew Patrick for their comments and suggestions, which have greatly helped to improve the manuscript. We acknowledge the NASA-LAADS (http://ladsweb.nascom.nasa.gov/) for providing night-time level 1b MODIS data.

\section{References}

Aiuppa, A., Federico, C., Giudice, G., Giuffrida, G., Guida, R., Guerrieri, S., Liuzzo, M., Moretti, R., Papale, P., 2009. The 2007 eruption of Stromboli volcano: insights from real-time measurement of the volcanic gas plume $\mathrm{CO} 2 / \mathrm{SO} 2$ ratio. Journal of Volcanology and Geothermal Research 182, 221-230. doi:10.1016/j.jvolgeores.2008.09.013.

Aiuppa, A., Bertagnini, A., Métrich, N., Moretti, R., Di Muro, A., Liuzzo, M., Tamburello, G., 2010. A model of degassing for Stromboli volcano. Earth and Planetary Science Letters 295 (1-2), 195-204.

Allard, P., Carbonnelle, J., Métrich, N., Loyer, H., Zettwoog, P., 1994. Sulphur output and magma degassing budget of Stromboli volcano. Nature 368, 326-330.

Allard, P., Aiuppa, A., Burton, M., Caltabiano, T., Federico, C., Salerno, G., La Spina, A., 2008. Crater gas emissions and the magma feeding system of Stromboli volcano. In: Calvari, S., Inguaggiato, S., Puglisi, G., Ripepe, M., Rosi, M. (Eds.), Learning from Stromboli: AGU Geophysics Monograph Series, 182, pp. 65-80.

Barberi, F., Rosi, M., Sodi, A., 1993. Volcanic hazard assessment at Stromboli based on review of historical data. Acta Vulcanologica 3, 173-187.

Barberi, F., Civetta, L., Rosi, M., Scandone, R., 2009. Chronology of the 2007 eruption of Stromboli and the activity of the Scientific Synthesis Group. Journal of Volcanology and Geothermal Research 182, 123-130.

Burton, M.R., Mader, H.M., Polacci, M., 2007. The role of gas percolation in quiescent degassing of persistently active basaltic volcanoes. Earth and Planetary Science Letters 264, 46-60. doi:10.1016/j.epsl.2007.08.028.

Burton, M., Calvari, S., Spampinato, L., Lodato, L., Pino, N.A., Marchetti, E., Murè, F., 2008. Volcanic and seismic activity at Stromboli preceding the 2002-2003 flank eruption. In: Calvari, S., Inguaggiato, S., Puglisi, G., Ripepe, M., Rosi, M. (Eds.), The Stromboli volcano: an integrated study of the 2002-2003 eruption: AGU Gephys Monograph Series, 182, pp. 93-104

Calvari, S., Spampinato, L., Lodato, L., Harris, A.J.L., Patrick, M.R., Dehn, J., Burton, M.R., Andronico, D., 2005. Chronology and complex volcanic processes during the 2002-2003 flank eruption at Stromboli volcano (Italy) reconstructed from direct observations and surveys with a hand-held thermal camera. Journal of Geophysical Research 110, B02201. doi:10.1029/2004JB003129.

Calvari, S., Lodato, L., Steffke, A., Cristaldi, A., Harris, A.J.L., Spampinato, L., Boschi, E., 2010. The 2007 Stromboli flank eruption: chronology of the events, and effusion rate measurements from thermal images and satellite data. Journal of Geophysical Research 115 (B4), B04201. doi:10.1029/2009JB006478.

Calvari, S., Spampinato, L., Bonaccorso, A., Oppenheimer, C., Rivalta, E., Boschi, E., 2011. Lava effusion-a slow fuse for paroxysms at Stromboli volcano? Earth and Planetary Science Letters 301 (1-2), 317-323.

Chouet, B., Dawson, P., Ohminato, T., Martini, M., Saccarotti, G., Giudicepietro, F., De Luca, G., Milana, G., Scarpa, R., 2003. Source mechanisms of explosions at Stromboli Volcano, Italy, determined from moment-tensor inversions of very-long-period data. Journal of Geophysical Research 108, 1-25. doi:10.1029/2002JB001919.

Cigolini, C., Laiolo, M., Bertolino, S., 2008. Probing Stromboli volcano from the mantle to paroxysmal eruptions. In: Annen, C., Zellmer, G. (Eds.), Dynamics of crustal magma transfer, storage, and differentiation-integrating geochemical and geophysical constraints. : Geological Society, 304. Special Publication, London, pp. 33-70.

Flynn, L.P., Wright, R., Garbeil, H., Harris, A.J.L., Pilger, E., 2002. A global thermal alert using MODIS: initial results from 2000-2001. Advances in Environmental Monitoring and Modeling 1,5-36.

Francalanci, L., Davies, G.R., Lustenhouwer, W., Tommasini, S., Mason, P.R., Conticelli, S., 2005. Intra-grain Sr isotope evidence for crystal recycling and multiple magma reservoirs in the recent activity of Stromboli volcano, Southern Italy. Journal of Petrology 46, 1997-2021.
Giglio, L., Descloitresa, J., Justicec, C.O., Kaufman, Y.J., 2003. An enhanced contextual fire detection algorithm for MODIS. Remote Sensing of Environment 87, 273-282.

Harris, A.J.L., Neri, M., 2002. Volumetric observations during paroxysmal eruptions at Mount Etna: pressurised drainage of a shallow chamber or pulsed supply? Journal of Volcanology and Geothermal Research 116, 79-95.

Harris, A.J.L., Ripepe, M., 2007a. Temperature and dynamics of degassing at Stromboli. Journal of Geophysical Research 112. doi:10.1029/2006JB0004393.

Harris, A.J.L., Ripepe, M., 2007b. Synergy of multiple geophysical approaches to unravel explosive eruption conduit and source dynamics-a case study from Stromboli. Chemie der Erde 67, 1-35.

Harris, A.J.L., Stevenson, D.S., 1997a. Thermal observations of degassing open conduits and fumaroles at Stromboli and Vulcano using remotely sensed data. Journal of Volcanology and Geothermal Research 76, 175-198.

Harris, A.J.L., Stevenson, D.S., 1997b. Magma budgets and steady-state activity of Vulcano and Stromboli volcanoes. Geophysical Research Letters 24, 1043-1046.

Harris, A.J.L., Carniel, R., Jones, J., 2005. Identification of variable convective regimes at Erta'Ale lava lake. Journal of Volcanology and Geothermal Research 142, 207-223. doi:10.1016/j.jvolgeores.2004.11.011.

INGV Report, 2010. Bollettino settimanale sul monitoraggio vulcanico, geochimico, delle deformazioni del suolo e sismico del vulcano Stromboli del 21/12/2010Available at http://www.pa.ingv.it/2010.

INGV Report, 2011a. Bollettino settimanale sul monitoraggio vulcanico, geochimico, delle deformazioni del suolo e sismico del vulcano Stromboli del 01/02/2011Available at http://www.pa.ingv.it/2011.

INGV Report, 2011b. In Rapporti di Vulcanologia: “Sopralluogo a Stromboli del 2 agosto 2011"Available at http://www.ct.ingv.it/2011.

Koeppen, W.C., Pilger, E., Wright, R., 2011. Time series analysis of infrared satellite data for detecting thermal anomalies: a hybrid approach. Bulletin of Volcanology 73, 577-593. doi:10.1007/s00445-010-0427-y.

Landi, P., Francalanci, L., Pompilio, M., Rosi, M., Corsaro, R.A., Petrone, C.M., Cardini, I., Miraglia, L., 2006. The December 2002-July 2003 effusive event at Stromboli next term volcano, Italy: insights into the shallow plumbing system by petrochemical studies. Journal of Volcanology and Geothermal Research 155 (3-4), 263-284.

Lautze, N.C., Houghton, B.F., 2005. Physical mingling of magma and complex eruption dynamics in the shallow conduit at Stromboli volcano, Italy. Geology 33, 425-428.

Lautze, N.C., Houghton, B.F., 2007. Linking variable explosion style and magma textures during 2002 at Stromboli volcano, Italy. Bulletin of Volcanology 69, 445-460.

Lautze, N.C., Harris, A.J.L., Bailey, J.E., Ripepe, M., Calvari, S., Dehn, J., Rowland, S.K., Evans-Jones, K., 2004. Pulsed lava effusion at Mount Etna during 2001. Journal of Volcanology and Geothermal Research 137, 231-246.

Liu, L., Wen, X., Dong, X., Dai, Q., 2008. A new prompt algorithm for removing bowtie effect of MODIS L1b data. Image and Signal Processing 2008 (5), 663-667. doi:10.1109/CISP.2008.404

Lodato, L., Spampinato, L., Harris, A.J.L., Calvari, S., Dehn, J., Patrick, M.R., 2007. The morphology and evolution of the Stromboli 2002-03 lava flow field: an example of a basaltic flow field emplaced on a steep slope. Bulletin of Volcanology 69, 661-679.

Marchese, F., Ciampa, M., Filizzola, C., Lacava, T., Mazzeo, G., Pergola, N., Tramutoli, V., 2010. On the exportability of robust satellite techniques (RST) for active volcano monitoring. Remote Sensing 2 (6), 1575-1588.

Marchetti, E., Ripepe, M., Harris, A.J.L., Delle Donne, D., 2009. Tracing the differences between Vulcanian and Strombolian explosions using infrasonic and thermal energy. Earth and Planetary Science Letters 279, 273-281.

Marsella, M., Proietti, C., Sonnessa, A., Coltelli, M., Tommasi, P., Bernardo, E., 2009. The evolution of the Sciara del Fuoco subaerial slope during the 2007 Stromboli eruption: relation between deformation processes and effusive activity. Journal of Volcanology and Geothermal Research 182 (3-4), 201-213.

Marsella, M., Baldi, P., Coltelli,M., Fabris, M., in press. The morphological evolution of the Sciara del Fuoco since 1868: reconstructing the effusive activity at Stromboli volcano. Bulletin of Volcanology: DOI: 10.1007/s00445-011-0516-6.

Mètrich, N.A., Bertagnini, A., Di Muro, A., 2010. Conditions of magma storage, degassing and ascent at Stromboli: new insights into the volcano plumbing system with inferences on the eruptive dynamics. Journal of Petrology 51, 603-626.

Neri, M., Lanzafame, G., 2008. Structural features of the 2007 Stromboli eruption. Journal of Volcanology and Geothermal Research 182 (3-4), 137-144.

Neuberg, J., Lucckett, R., Ripepe, M., Braun, T., 1994. Highlights from a seismic broadband array on Stromboli volcano. Geophysical Research Letters 21, 749-752. doi:10.1029/94GL00377.

Nishihama, M., Wolfe, R.E., Solomon, D., Patt, F.S., Blanchette, J., Fleig, A.J., Masuoka, E., 1997. MODIS Level 1A Earth Location Algorithm Theoretical Basis Document Version 3.0. SDST-092, Lab. Terrestrial Phys. NASA Goddard Space Flight Center, Greenbelt, MD.

Patrick, M., Harris, A.J.L., Ripepe, M., Dehn, J., Rothery, D.A., Calvari, S., 2007. Strombolian explosive styles and source conditions: insights from thermal (FLIR) video. Bulletin of Volcanology 69, 769-784. doi:10.1007/s00445-006-0107-0.

Pergola, N., Marchese, F., Tramutoli, V., 2004. Automated detection of thermal features of active volcanoes by means of Infrared AVHRR records. Remote Sensing of Environment 93, 311-327.

Piscopo, D., 2010. Stromboli MODIS thermal anomalies during Strombolian activity. PhD Thesis, Dipartimento di Scienze Mineralogiche e Petrologiche, Università di Torino. pp. 119.

Ripepe, M., Ciliberto, S., Della Schiava, M., 2001. Time constraints for modeling source dynamics of volcanic explosions at Stromboli. Journal of Geophysical Research 106 (B5), 8713-8727.

Ripepe, M., Harris, A.J.L., Carniel, R., 2002. Thermal, seismic and infrasonic evidences of variable degassing rates at Stromboli volcano. Journal of Volcanology and Geothermal Research 118, 285-297. doi:10.1016/S0377-0273(02)00298-6. 
Ripepe, M., Marchetti, E., Ulivieri, G., Harris, A., Dehn, J., Burton, M., Caltabiano, T., Salerno, G., 2005. The effusive to explosive transition during the 2002 eruption of Stromboli volcano. Geology 33 (5), 341-344.

Ripepe, M., Delle Donne, D., Harris, A., 2008. Dynamics of strombolian activity. In: Calvari, S., Rosi, M., Ripepe, M. (Eds.), Learning from Stromboli and its 2002-2003 Eruptive Crisis: American Geophysical Union-Geophysical Monograph volume.

Ripepe, M., Delle Donne, D., Lacanna, G., Marchetti, E., Ulivieri, G., 2009. The onset of the 2007 Stromboli effusive eruption recorded by an integrated geophysical network. Journal of Volcanology and Geothermal Research 182, 131-136.

Rizzo, A., Grassa, F., Ingaggiato, S., Lotta, M., Longo, M., Madonna, P., Brusca, L., Papasso, G., Morici, S., Rouwet, D., Vita, F., 2009. Geochemical evaluation of observed changes in volcanic activity during the 2007 eruption at Stromboli (Italy). Journal of Volcanology and Geothermal Research 246-254. doi:10.1016/j.jvolgeores.2008.08.004.

Rosi, M., Bertagnini, A., Landi, P., 2000. Onset of persisting activity at Stromboli Volcano (Italy). Bulletin of Volcanology 62, 294-300.

Rothery, D.A., Coltelli, M., Pirie, D., Wooster, M.J., Wright, R., 2001. Documenting surface magmatic activity at Mount Etna using ATSR remote sensing. Bulletin of Volcanology 63, 387-397.

Rothery, D.A., Coppola, D., Saunders, C., 2005. Analysis of volcanic activity patterns using MODIS thermal alerts. Bulletin of Volcanology 67 (6), 539-556.

Rymer, H., Wyk, Van, de Vries, B., Stix, J., Williams-Jones, G., 1998. Pit crater structure and processes governing persistent activity at Masaya Volcano, Nicaragua. Bulletin of Volcanology 59, 345-355.

Smithsonian Institution, 2004. Stromboli. Bulletin of the Global Volcanism Network 29 (3).

Smithsonian Institution, 2010. Stromboli. Bulletin of the Global Volcanism Network 35 (3).
Steffke, A.M., Harris, A.J.L., 2011. A review of algorithms for detecting volcanic hotspot in satellite infrared data. Bulletin of Volcanology 73, 1109-1137. doi:10.1007/ s00445-011-0487-7.

Vaughan, R.G., Kervyn, M., Realmuto, V., Abrams, M., Hook, S.J., 2008. Satellite measurements of recent volcanic activity at Oldoinyo Lengai, Tanzania. Journal of Volcanology and Geothermal Research 173 (3-4), 196-206.

Witham, F., Woods, A.W., Gladstone, C., 2006. An analogue experimental model of depth fluctuations in lava lakes. Bulletin of Volcanology 69, 51-56. doi:10.1007/ s00445-006-0055-8.

Wooster, M.J. Zhukov, B., Oertel, D., 2003. Fire radiative energy for quantitative study of biomass burning: derivation from the BIRD experimental satellite and comparison to MODIS fire products. Remote Sensing of Environment 86, 83-107.

Wright, R., Pilger, E., 2008. Radiant flux from Earth's subaerially erupting volcanoes. International Journal of Remote Sensing 29 (22), 6443-6466. doi:10.1080/ 01431160802168210.

Wright, R., Flynn, L., Garbeil, H., Harris, A.J.L., Pilger, E., 2002a. Automated volcanic eruption detection using MODIS. Remote Sensing of Environment 82, 135-155.

Wright, R., De La Cruz-Reyna, S., Harris, A., Flynn, L., Gomez-Palacios, J.J., 2002b. Infrared satellite monitoring at Popocatépetl: explosions, exhalations, and cycles of dome growth. Journal of Geophysical Research 107 (8), 2-16.

Wright, R., Flynn, L.P., Garbeil, H., Harris, A.J.L., Pilger, E., 2004. MODVOLC: near-realtime thermal monitoring of global volcanism. Journal of Volcanology and Geothermal Research 135, 29-49. 